\title{
Asymmetry in Synergistic Interaction Between Wheat streak mosaic virus and Triticum mosaic virus in Wheat
}

\author{
Satyanarayana Tatineni, ${ }^{1+}{ }^{+}$Jeff Alexander, ${ }^{1}$ Adarsh K. Gupta, ${ }^{2}$ and Roy French ${ }^{1}$ \\ ${ }^{1}$ United States Department of Agriculture-Agricultural Research Service and Department of Plant Pathology and ${ }^{2}$ Department \\ of Plant Pathology, University of Nebraska-Lincoln, Lincoln 68583, U.S.A.
}

Accepted 10 August 2018.

\begin{abstract}
Wheat streak mosaic virus (WSMV) and Triticum mosaic virus (TriMV), distinct members in the family Potyviridae, are economically important wheat-infecting viruses in the Great Plains region. Previously, we reported that coinfection of wheat by WSMV and TriMV caused disease synergism with increased concentration of both viruses. The mechanisms of synergistic interaction between WSMV and TriMV and the effects of prior infection of wheat by either of these "synergistically interacting partner" (SIP) viruses on the establishment of local and systemic infection by the other SIP virus are not known. In this study, using fluorescent protein-tagged viruses, we found that prior infection of wheat by WSMV or TriMV negatively affected the onset and size of local foci elicited by subsequent SIP virus infection compared with those in buffer-inoculated wheat. These data revealed that prior infection of wheat by an SIP virus has no measurable advantage for another SIP virus on the initiation of infection and cell-to-cell movement. In TriMV-infected wheat, WSMV exhibited accelerated longdistance movement and increased accumulation of genomic RNAs compared with those in buffer-inoculated wheat, indicating that TriMV-encoded proteins complemented WSMV for efficient systemic infection. In contrast, TriMV displayed delayed systemic infection in WSMV-infected wheat, with fewer genomic RNA copies in early stages of infection compared with those in buffer-inoculated wheat. However, during late stages of infection, TriMV accumulation in WSMV-infected wheat increased rapidly with accelerated long-distance movement compared with those in buffer-inoculated wheat. Taken together, these data suggest that interactions between synergistically interacting WSMV and TriMV are asymmetrical; thus, successful establishment of synergistic interaction between
\end{abstract}

USDA is an equal opportunity provider and employer. Mention of trade names or commercial products in this publication is solely for the purpose of providing specific information and does not imply recommendation or endorsement by the U.S. Department of Agriculture.

Roy French is deceased.

${ }^{\dagger}$ Corresponding author: Satyanarayana Tatineni;

E-mail: satya.tatineni@ars.usda.gov

Funding: This work was funded by the United States Department of Agriculture (USDA)-Agricultural Research Service Current Research Information System (5440-21000-033-00D) and partially funded by USDA-National Institute of Food and Agriculture (2013-68004-20358).

This article is in the public domain and not copyrightable. It may be freely reprinted with customary crediting of the source. The American Phytopathological Society, 2019. unrelated viruses will depend on the order of infection of plants by SIP viruses.

Most plant viruses spread in nature through horizontal transfer by vectors. The majority of these vectors are reported to transmit more than one virus to the same or different hosts (Whitfield et al. 2015). Thus, mixed infections of plants with more than one virus are common in nature, and these mixed infections facilitate two types of virus-virus interactions, depending on the sequence homology between interacting viruses (Mascia and Gallitelli 2016; Syller 2012; Syller and Grupa 2016). Antagonistic interactions between related viruses exclude coinfection of the same cell by closely related viruses. This phenomenon is known as superinfection exclusion (SIE) or cross protection (Syller and Grupa 2016; Zhang et al. 2018). In contrast, facilitative or synergistic interactions enable coinfection of the same cell by unrelated viruses. These interactions result in an acute disease phenotype with an increase in virus titer of one or all interacting viruses compared with infections by individual viruses (Mascia and Gallitelli 2016; Syller 2012). Synergistic interactions have been shown to cause significant damage to agriculturally important crops such as maize (Zea mays L.), cassava (Manihot esculenta Crantz), and sweet potato (Ipomoea batatas L.) (Mascia and Gallitelli 2016; Syller 2012). For example, synergistic interaction between Maize chlorotic mottle virus and a potyvirus resulted in maize lethal necrosis disease (Mahuku et al. 2015; Redinbaugh and Stewart 2018), Cassava brown streak virus and Ugandan Cassava brown streak virus caused cassava brown streak disease (Patil et al. 2015), and Sweet potato feathery mottle virus and Sweet potato chlorotic stunt virus elicited sweet potato virus disease (Gutiérrez et al. 2003; Karyeija et al. 2000).

Synergism between Potato virus $X$ (PVX, a potexvirus) and potyviruses has been thoroughly characterized (González-Jara et al. 2005; Pruss et al. 1997; Shi et al. 1997; Vance 1991; Vance et al. 1995). Coinfection of tobacco plants by PVX and Potato virus $Y$ (PVY), Tobacco etch potyvirus (TEV), or Plum pox potyvirus (PPV) elicited severe disease symptoms with a drastic increase in PVX titer but no significant change in potyvirus titer compared with infections by the viruses individually (Vance 1991; González-Jara et al. 2004, 2005). Conversely, coinfection of a potyvirus with Tobacco mosaic virus (TMV) or with Potato spindle tuber viroid caused a significant increase in potyvirus accumulation compared with individual infections by the viruses or viroid (Valkonen 1992). Synergistic interaction between Cucumber mosaic virus (CMV) and PVY caused severe disease with increased accumulation of CMV but decreased accumulation of PVY compared with infections by 
A

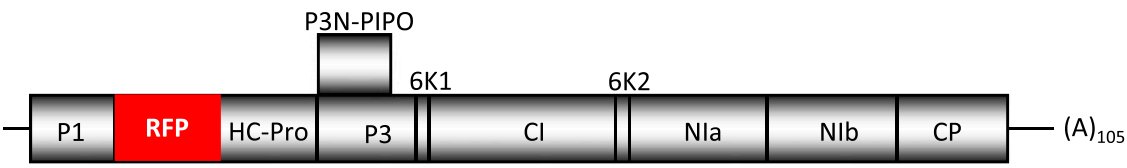

WSMV-RFP-6K1/CI(7aa)

(WSMV-RFP)

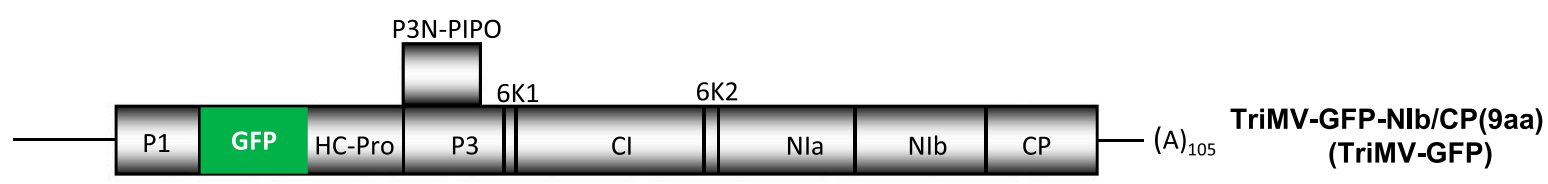

B
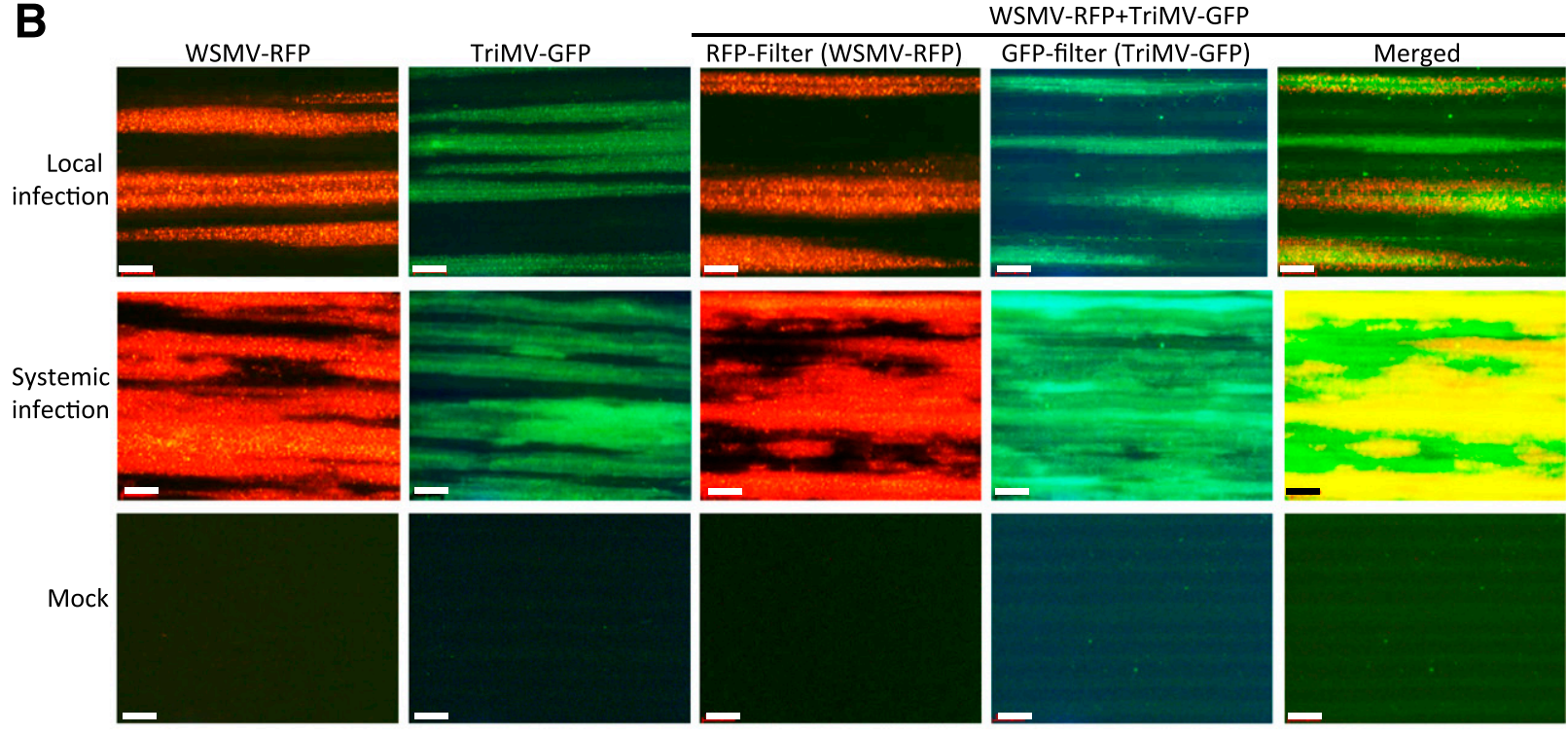

C
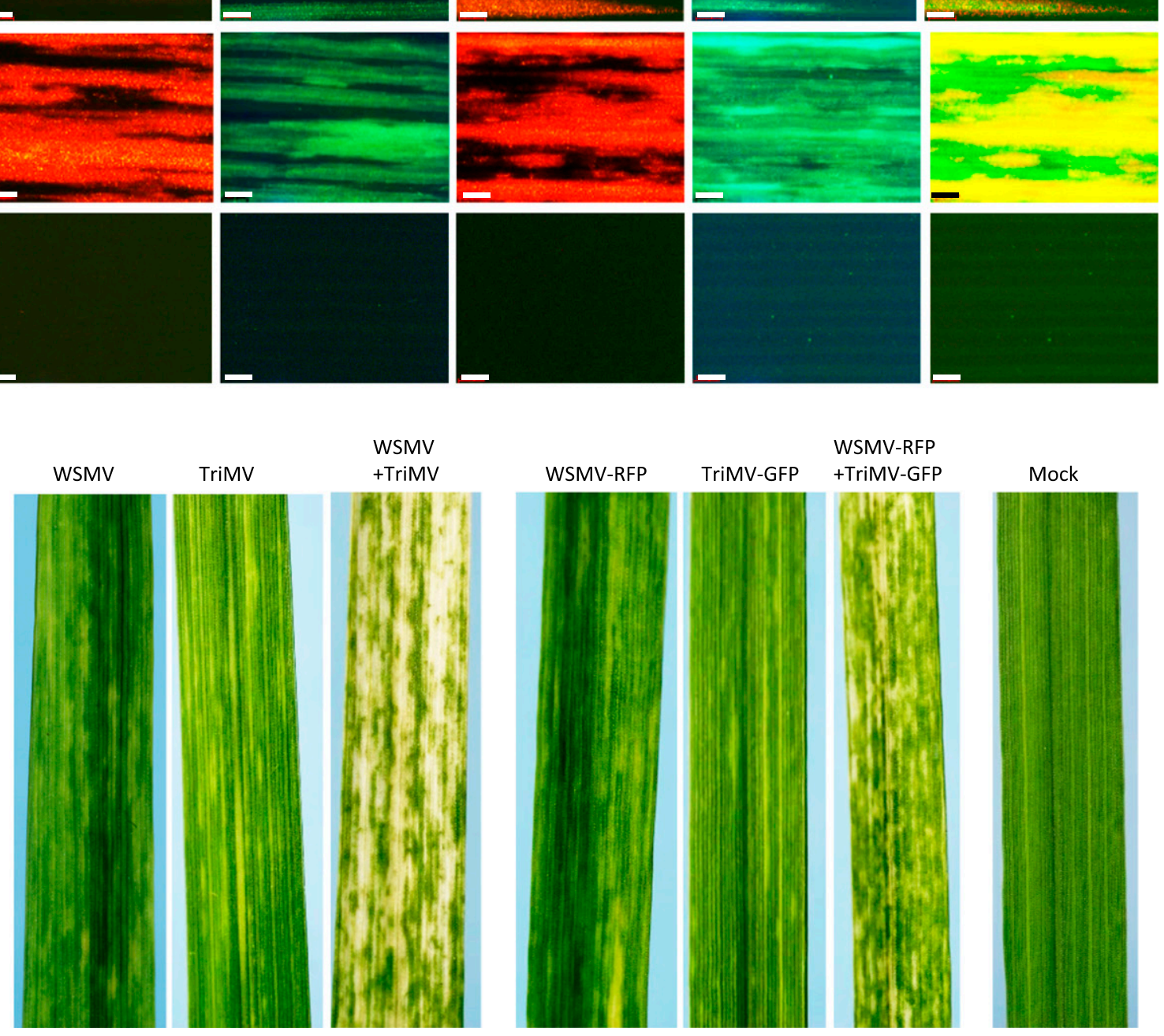

Fig. 1. Synergistic interaction of fluorescent protein-tagged Wheat streak mosaic virus (WSMV) and Triticum mosaic virus (TriMV) in coinfected wheat. A, Genome organization of a red fluorescent protein (RFP)-tagged WSMV (Tatineni et al. 2016) and a green fluorescent protein (GFP)-tagged TriMV (Tatineni et al. 2015) with virus-encoded proteins indicated. The RFP and GFP open reading frames were inserted into WSMV and TriMV genomes, respectively, between the P1 and HC-Pro cistrons. 6K1/CI(7aa) and NIb/CP(9aa) in WSMV-RFP-6K1/CI(7aa) and TriMV-GFP-NIb/CP(9aa), respectively, represent a cleavage site introduced between the sequences encoding for a fluorescent protein and HC-Pro cistron. B, Fluorescent images of wheat leaves showing single and double infections by WSMV-RFP and TriMV-GFP on inoculated leaves at 4 days postinoculation (dpi) and systemic infection at 14 dpi. Wheat leaves were observed under a Stereo Discovery V12 fluorescent microscope using RFP (for WSMV-RFP) or GFP (for TriMV-GFP) filters. Coinfection of wheat by WSMV-RFP and TriMV-GFP was observed using RFP and GFP filters, respectively, and merged images show coinfection by two viruses. Buffer-inoculated wheat leaves were observed under GFP and RFP filters as negative controls. Bars represent $500 \mu \mathrm{m}$. C, Symptoms elicited by wild-type or fluorescent protein-tagged WSMV, TriMV, or both on wheat cultivar Tomahawk at 14 dpi. Note that coinfection of wheat by fluorescent protein-tagged WSMV and TriMV induced severe symptoms. 
A

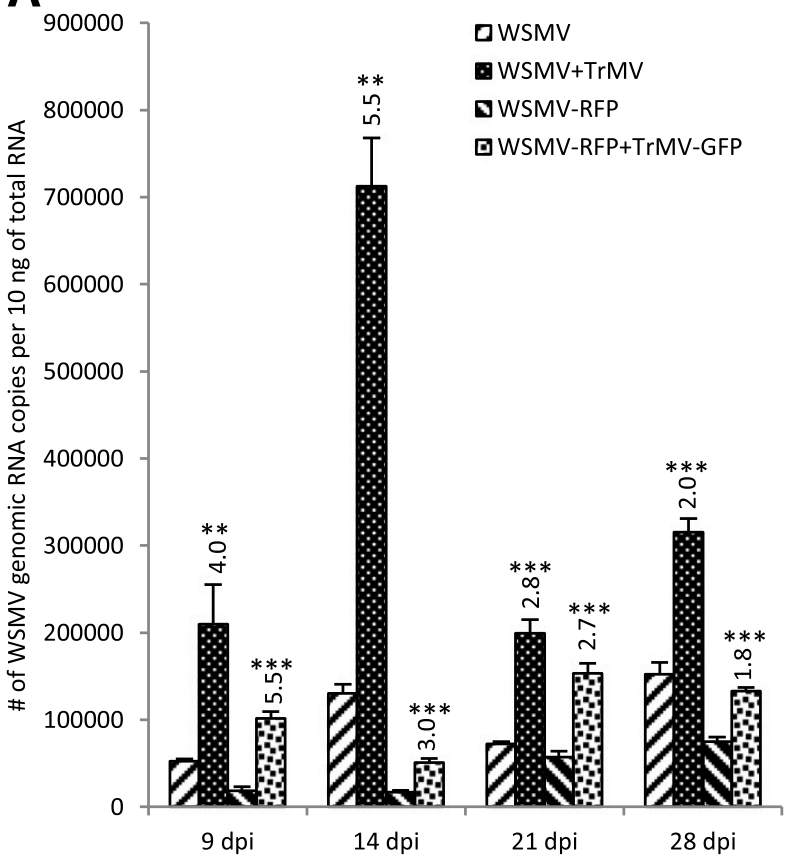

B

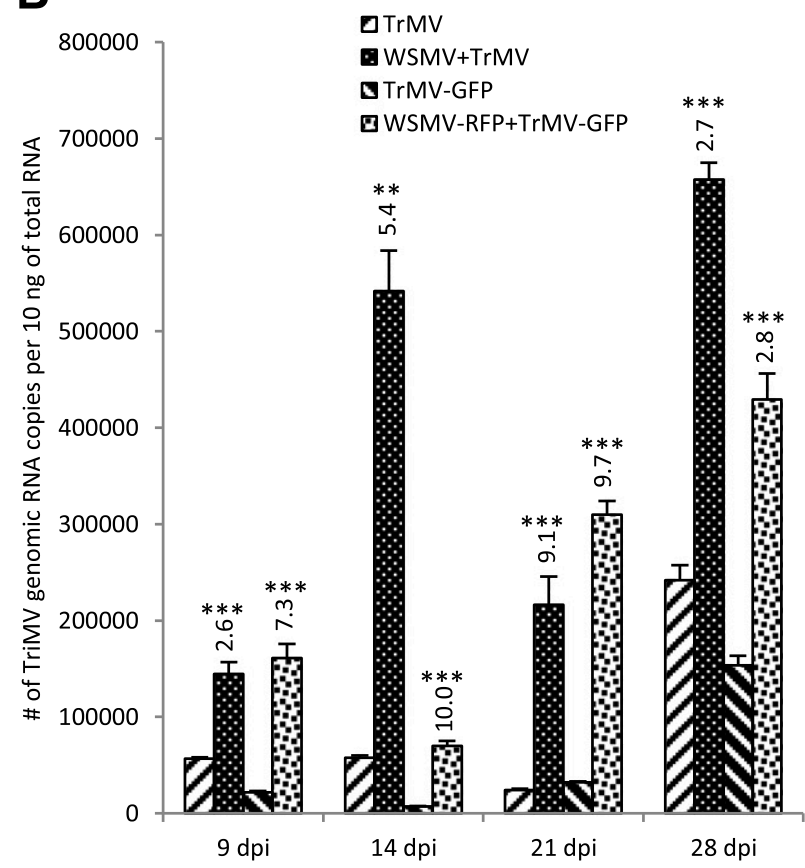

C

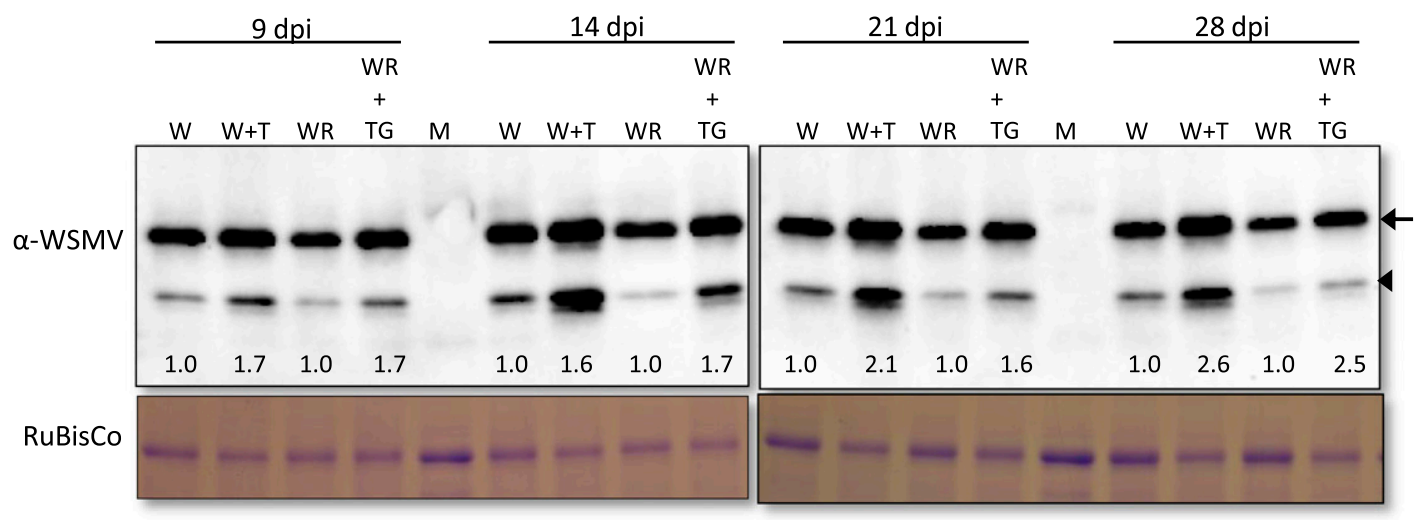

D

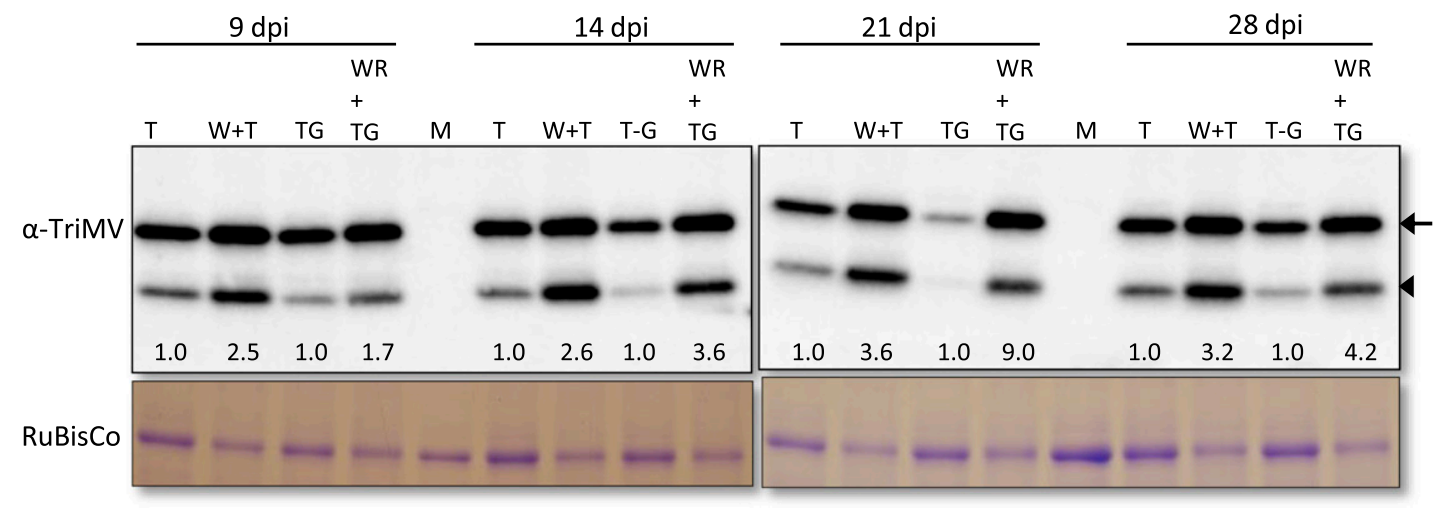

Fig. 2. Coinfection of wheat by wild-type or fluorescent protein-tagged Wheat streak mosaic virus (WSMV) and Triticum mosaic virus (TriMV) facilitated increased accumulation of individual viruses. A and B, Quantification of genomic RNA copies of WSMV (A) and TriMV (B) in singly and doubly infected wheat by wild-type or fluorescent protein-tagged WSMV, TriMV, or both at 9, 14,21, and 28 days postinoculation (dpi). Numbers presented above the histograms of doubly infected samples are the fold change in genomic RNA accumulation over the respective singly infected samples. Note that coinfection of wheat by wild-type or fluorescent protein-tagged WSMV and TriMV caused increased accumulation of genomic RNAs. RFP = red fluorescent protein, GFP $=$ green fluorescent protein, and $* *$ and $* * *$ represent statistical significance at the confidence interval of 95 and $99 \%$, respectively. $\mathbf{C}$ and $\mathbf{D}$, Western blot analyses of total proteins showing accumulation of coat protein (CP) in singly or doubly infected wheat by wild-type or fluorescent protein-tagged WSMV and TriMV at 9, 14, 21 and 28 dpi. Immunoblots were probed with polyclonal antibodies against WSMV virions (C) and TriMV CP (D). Numbers at the bottom of blots indicate fold-increase in CP accumulation in coinfected wheat over infections by individual viruses. The full-length CP and a truncated minor CP that reacted positively with WSMV or TriMV antibodies are indicated with arrows and arrowheads, respectively. Coomassie-stained sodium dodecyl sulfate polyacrylamide gel electrophoresis gels at the bottom of protein blots show wheat RuBisCO protein for the amount of total protein loaded per well. $\mathrm{W}=\mathrm{WSMV}, \mathrm{T}=$ TriMV, WR $=\mathrm{WSMV}-\mathrm{RFP}$, and TG = TriMV-GFP. 
individual viruses (Mascia et al. 2010). Interactions between two distinct virus species in maize, wheat (Triticum aestivum L.), and soybean (Glycine max L.) caused disease synergism with increased accumulation of both viruses (Malapi-Nelson et al. 2009; Scheets 1998; Stenger et al. 2007; Tatineni et al. 2010). The above studies suggest that synergistic interaction between unrelated viruses cause severe disease phenotypes with increased accumulation of one or both viruses, depending on the particular combination of interacting viruses (Mascia and Gallitelli 2016).

Wheat-infecting Wheat streak mosaic virus (WSMV) and Triticum mosaic virus (TriMV) are the type species of the genera Tritimovirus and Poacevirus, respectively, in the family Potyviridae (Fellers et al. 2009; Stenger et al. 1998; Tatineni et al. 2009). The genomes of both viruses contain single-stranded positivesense RNAs that are encapsidated in flexuous filamentous particles. The 9.4- and 10.2-kb genomic RNAs of WSMV and TriMV, respectively, encode large polyproteins of approximately $350 \mathrm{kDa}$, which are cleaved into mature proteins by three virus-encoded proteinases: P1, HC-Pro, and NIa-Pro (Stenger et al. 1998; Tatineni et al. 2009). The P1 proteins of WSMV and TriMV have been reported as viral suppressors of RNA silencing and enhancers of pathogenicity (Tatineni et al. 2012; Young et al. 2012). The HCPro proteins of WSMV and TriMV are dispensable for systemic infection of wheat but are required for efficient virus accumulation (Stenger et al. 2005b) (S. Tatineni, unpublished). The coat protein (CP) and NIa-Pro of WSMV and TriMV are identified as independent effectors of SIE (Tatineni and French 2016). The CP and P3N-PIPO of WSMV are required for cell-to-cell and longdistance movement and for extension of host range through hostspecific long-distance transport (Choi et al. 2005; Tatineni et al. 2011b, 2013). WSMV CP amino acids 36 to 84 are dispensable for efficient systemic infection of wheat but mutants lacking these
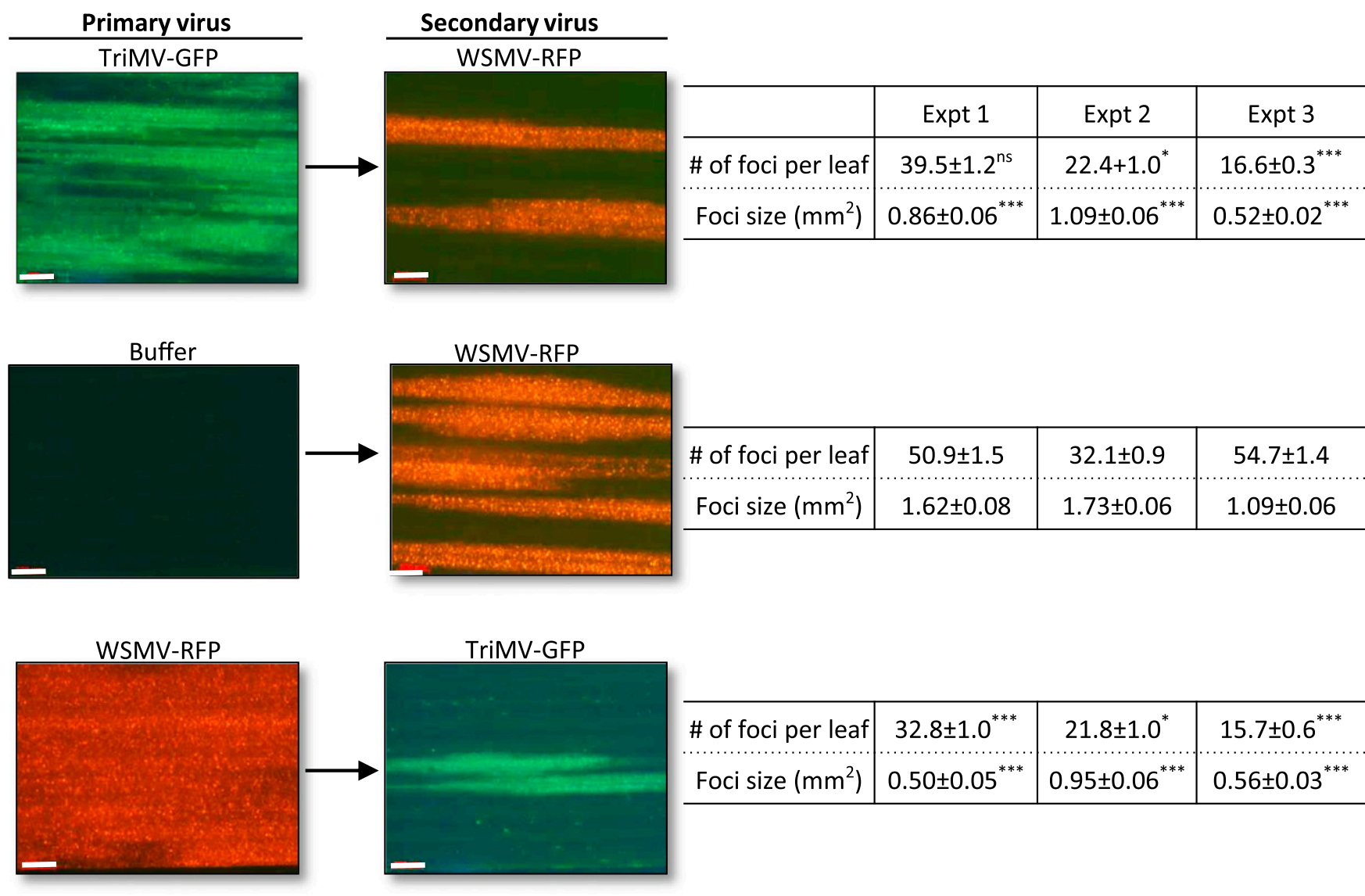

\begin{tabular}{c|c|c|c}
\hline \# of foci per leaf & $32.8 \pm 1.0^{* * *}$ & $21.8 \pm 1.0^{*}$ & $15.7 \pm 0.6^{* * *}$ \\
\hdashline Foci size $\left(\mathrm{mm}^{2}\right)$ & $0.50 \pm 0.05^{* *}$ & $0.95 \pm 0.06^{* *}$ & $0.56 \pm 0.03^{* *}$ \\
\hline
\end{tabular}
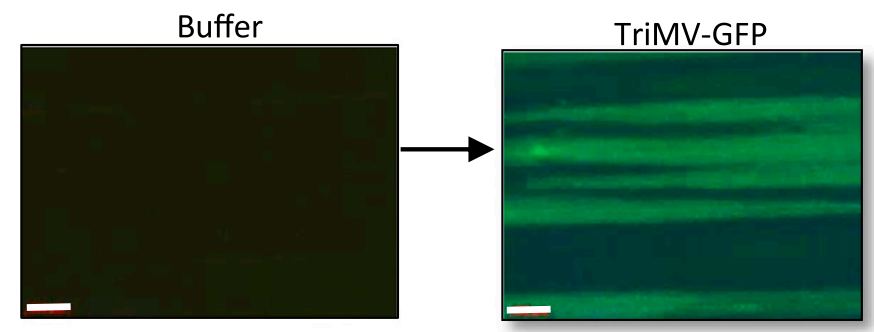

\begin{tabular}{|c|c|c|c|}
\hline \# of foci per leaf & $52.9 \pm 1.4$ & $28.3 \pm 0.9$ & $47.7 \pm 1.0$ \\
\hline Foci size (mn & $0.84 \pm 0.05$ & $1.49 \pm 0.06$ & $1.23 \pm 0.07$ \\
\hline
\end{tabular}

Fig. 3. Systemic infection of wheat plants by Wheat streak mosaic virus (WSMV) or Triticum mosaic virus (TriMV) affected the establishment of local infection by the respective "synergistically interacting partner" (SIP) virus. Wheat seedlings were inoculated at the single-leaf stage with the primary virus (TriMV-green fluorescent protein [GFP], WSMV-red fluorescent protein [RFP], or buffer), followed by the secondary SIP virus (WSMV-RFP or TriMV-GFP) on a fully expanded third leaf at 10 days postinoculation. Fluorescent images of wheat leaves show systemically infected leaves by TriMV-GFP, WSMV-RFP, or buffer (left column), and local fluorescent foci elicited by WSMV-RFP or TriMV-GFP on primary virus-infected wheat leaves (right column). Wheat inoculated with buffer was used as a control. Number of local foci and size of foci elicited by the secondary virus on wheat infected by the primary virus is presented from three independent experiments \pm standard error. Symbols: *, ***, and ns represent statistical significance at confidence interval of 90 and $99 \%$ and not significant, respectively. Bars represent $500 \mu \mathrm{m}$. 
amino acids failed to infect oat (Avena sativa L.) and elicited severe symptoms in multiple cereal hosts with increased virus accumulation (Tatineni 2017; Tatineni et al. 2017).

WSMV is an economically important wheat virus with 2 to $5 \%$ annual yield loss and $100 \%$ yield loss in localized infections (Brakke 1987; French and Stenger 2004). TriMV is widespread in the Great Plains region but its impact on wheat yield is unknown because it is a recently reported virus (Burrows et al. 2009; Byamukama et al. 2013; Seifers et al. 2008). WSMV and TriMV are transmitted by the wheat curl mite

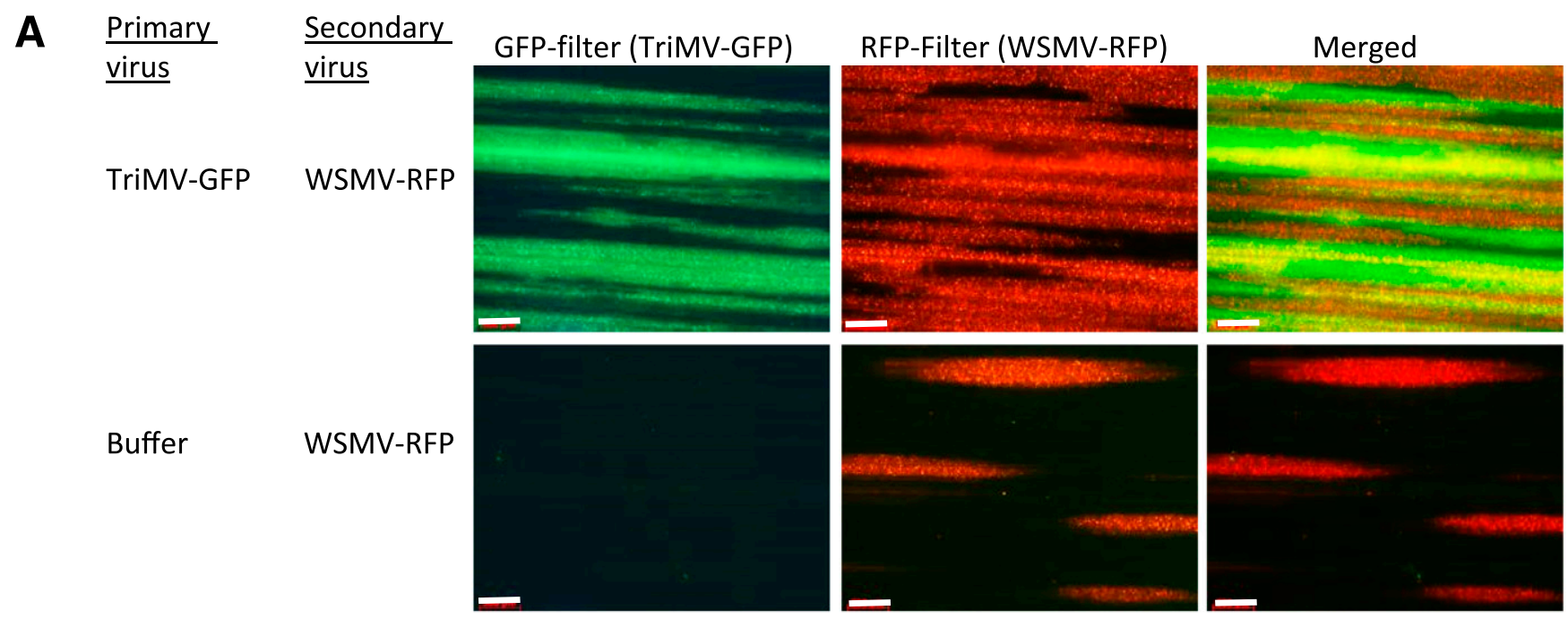

B

TriMV-GFP WSMV-RFP
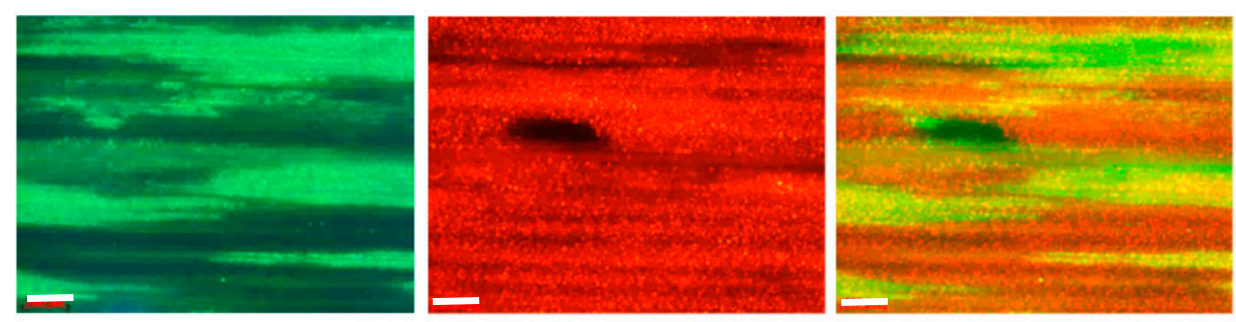

Buffer

WSMV-RFP
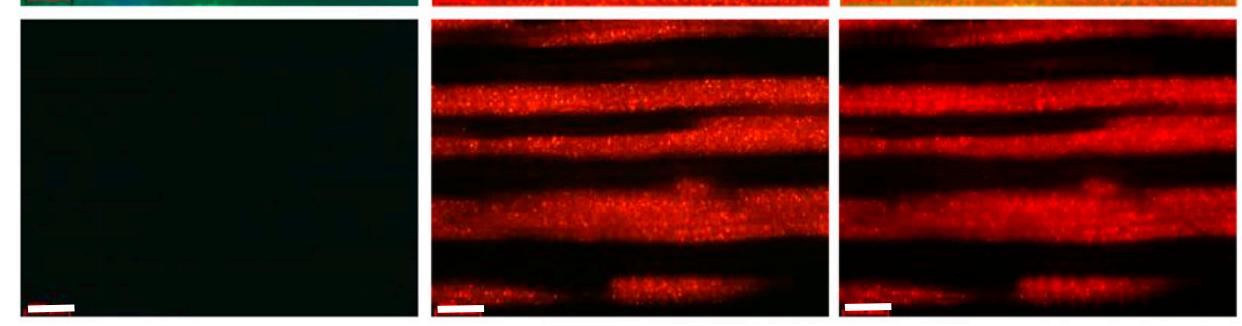

C
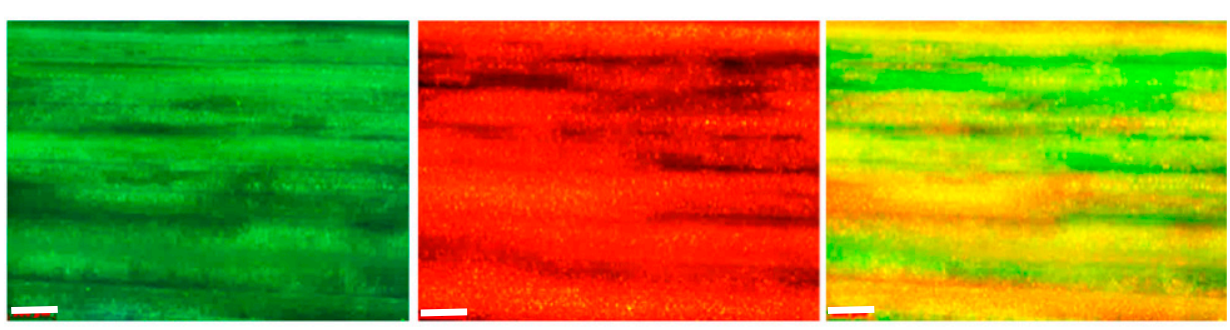

TriMV-GFP WSMV-RFP
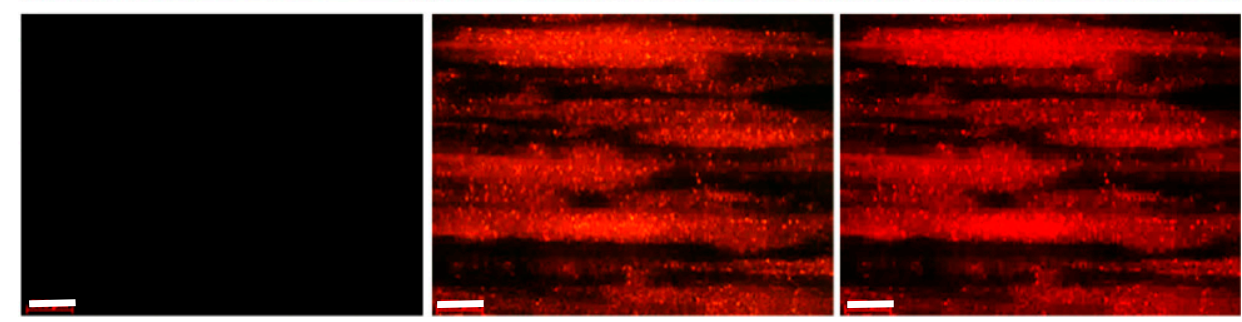

Fig. 4. Prior infection of wheat by Triticum mosaic virus (TriMV) facilitated accelerated long-distance movement of Wheat streak mosaic virus (WSMV). Wheat infected by TriMV-green fluorescent protein (GFP) at 10 days postinoculation (dpi) was inoculated with WSMV-red fluorescent protein (RFP), and fluorescent images of wheat leaves were obtained showing systemic infection by the primary virus (TriMV-GFP) and secondary virus (WSMV-RFP) at A, 16 days postprimary virus inoculation (dppvi) and 6 days postsecondary virus inoculation (dpsvi); B, 18 dppvi and 8 dpsvi; and C, 24 dppvi and 14 dpsvi. Infection by TriMV-GFP and WSMV-RFP was observed under a Stereo Discovery V12 fluorescent microscope using GFP and RFP filters, respectively, and merged images indicate coinfection by TriMV-GFP and WSMV-RFP. Bars represent $500 \mu \mathrm{m}$. 
(Aceria tosichella Keifer) (McMechan et al. 2014; Seifers et al. 2009; Slykhuis 1955), and HC-Pro and CP are identified as WSMV determinants for wheat curl mite transmission (Stenger et al. 2005a, 2006; Tatineni et al. 2018). There is no information on the requirement of TriMV-encoded proteins for wheat curl mite transmission. Because both WSMV and TriMV are transmitted by wheat curl mites, double infections in fieldgrown wheat are common, resulting in exacerbated yield losses (Burrows et al. 2009; Byamukama et al. 2014). In growers' fields, TriMV is found mostly as coinfected with WSMV (Byamukama et al. 2013). WSMV and TriMV interact synergistically in coinfected wheat, with dramatically increased disease severity and yield loss and with elevated accumulation of both viruses (Byamukama et al. 2012, 2014; Tatineni et al. 2010). However, the mechanisms of synergistic interaction between WSMV and TriMV are not known.

Though most economically important viral diseases of staple food crops are the result of synergistic interactions between unrelated viruses (Mahuku et al. 2015; Mascia and Gallitelli 2016; Patil et al. 2015; Redinbaugh and Stewart 2018), the mechanisms of these interactions are poorly understood. Severe disease phenotypes of synergistic interactions could be due to efficient suppression of host defense mechanisms through additive effects of dual viral suppressors of RNA silencing of interacting viruses. Potyviral HC-Pro, the suppressor of RNA silencing, was reported to be involved in synergistic interaction with PVX, CMV, and TMV (Pruss et al. 1997; Shi et al. 1997; Vance 1991) by suppressing posttranscriptional gene silencing (González-Jara et al. 2005) and interfering with miRNA-guided cleavage (Kasschau et al. 2003). Additionally, virus-encoded movement proteins have also been reported to play an important role in synergistic interaction, as shown with CMV 3a (Fukuzawa et al. 2010) and P3N-PIPO of a potyvirus (Hisa et al. 2014). In contrast to PVX and potyvirus interaction in tobacco, the order of infection in papaya by Papaya ringspot potyvirus and Papaya mosaic potexvirus determines whether an antagonistic or synergistic interaction results (Chávez-Calvillo et al. 2016).

Under field conditions, it is unlikely that a susceptible plant will be infected simultaneously by two or more unrelated viruses by vectors. Instead, individual viruliferous vectors harboring unrelated viruses could infect susceptible hosts at different time points. It is not known whether prior infection of plants by a "synergistically interacting partner" (SIP) virus has any effect on the development of local (at the site of infection) and systemic (in upper uninoculated leaves) infection by another SIP virus. In this study, we used WSMV and TriMV as SIP viruses to examine the effect of prior infection of wheat by either of SIP virus on synergistic interaction. Availability of a red fluorescent protein (RFP)-tagged WSMV (WSMV-RFP) and a green fluorescent protein (GFP)-tagged TriMV (TriMV-GFP) (Fig. 1A) facilitated the examination of the effect of prior infection of wheat by WSMV or TriMV on the establishment of synergistic interaction upon superinfection by its corresponding SIP virus.

\section{RESULTS}

\section{Synergistic interaction between}

fluorescent protein-tagged WSMV and TriMV in wheat.

To investigate the effect of prior infection of wheat by either SIP virus on the establishment of synergistic interaction, we first examined whether the fluorescent protein-tagged WSMV and TriMV interact synergistically in wheat. Wheat seedlings were inoculated at the single-leaf stage with WSMV-RFP, TriMVGFP, or both with crude sap of wheat leaves infected by in vitro transcripts of WSMV-RFP or TriMV-GFP. In coinoculated wheat leaves, overlapped foci were elicited by WSMV-RFP and TriMVGFP at 4 days postinoculation (dpi) (Fig. 1B, top panel). In doubly inoculated wheat, both GFP and RFP coexpressed in the same wheat cells in upper uninoculated leaves at 14 dpi (Fig. 1B, middle panel). These data, together with our previous results (Tatineni and French 2016), indicated that fluorescent proteintagged WSMV and TriMV coinfected wheat cells.

WSMV-RFP or TriMV-GFP developed mild chlorotic streaks and spots in upper uninoculated leaves at $7 \mathrm{dpi}$, followed by moderate chlorotic streaks and mosaic symptoms with slight stunting of plants by 14 dpi. Wild-type and RFP-tagged WSMV induced slightly severe chlorotic streaks and slight yellowing of leaves in wheat compared with wild-type TriMV and GFPtagged TriMV (Fig. 1C). Coinfection of wheat by WSMV-RFP and TriMV-GFP induced moderate chlorotic streaks and spots at $7 \mathrm{dpi}$, followed by severe chlorotic streaks and yellowing of leaves at $14 \mathrm{dpi}$ (Fig. 1C). By $21 \mathrm{dpi}$, coinoculated plants elicited stunting with severe leaf yellowing compared with mild mosaic and mottling symptoms elicited by each virus individually. Compared with wild-type viruses, coinfection of wheat by fluorescent protein-tagged WSMV and TriMV elicited slightly milder symptoms but significantly more severe symptoms compared with infections by each individual RFP or GFP-tagged virus (Fig. 1C). These data indicate that fluorescent protein-tagged WSMV and TriMV synergistically interacted in wheat and elicited more severe symptoms compared with infections by the viruses individually.

We next examined whether synergistic interaction between fluorescent protein-tagged WSMV and TriMV in wheat caused increased accumulation of individual viruses, as reported for wild-type viruses (Tatineni et al. 2010). Genomic RNA copies and $\mathrm{CP}$ accumulation of WSMV and TriMV were examined by real-time polymerase chain reaction (PCR) and Western blot analyses, respectively, in singly and doubly infected wheat by fluorescent protein-tagged and wild-type viruses. Accumulation of genomic RNA copies of wild-type and RFP-tagged WSMV showed a statistically significant increase of 2.0- to 5.5fold and 1.8- to 5.5-fold, respectively, at 9, 14, 21, and 28 dpi in doubly infected wheat compared with singly infected plants

Table 1. Effect of Triticum mosaic virus (TriMV) prior infection on Wheat streak mosaic virus (WSMV) systemic infection in wheat ${ }^{\mathrm{a}}$

\begin{tabular}{|c|c|c|c|c|c|c|c|c|}
\hline \multirow[b]{4}{*}{$\begin{array}{l}\text { Exp, } \\
\text { dpsvib }^{b}\end{array}$} & \multicolumn{8}{|c|}{ Systemic infection of WSMV-RFP } \\
\hline & \multicolumn{4}{|c|}{$\begin{array}{c}\text { In TriMV-GFP-infected } \\
\text { wheat }\end{array}$} & \multicolumn{4}{|c|}{ In buffer-inoculated wheat } \\
\hline & \multirow[b]{2}{*}{$\begin{array}{c}\text { Inoc } \\
(n)\end{array}$} & \multicolumn{3}{|c|}{$\begin{array}{l}\text { Plants with RFP } \\
\text { expression }(\%)\end{array}$} & \multirow[b]{2}{*}{$\begin{array}{c}\text { Inoc } \\
(n)\end{array}$} & \multicolumn{3}{|c|}{$\begin{array}{l}\text { Plants with RFP } \\
\text { expression }(\%)\end{array}$} \\
\hline & & Strong & Weak & $\begin{array}{l}\text { No } \\
\text { RFP }\end{array}$ & & Strong & Weak & $\begin{array}{l}\text { No } \\
\text { RFP }\end{array}$ \\
\hline \multicolumn{9}{|l|}{ I } \\
\hline $6 * * *$ & 16 & 81 & 6 & 13 & 12 & 0 & 75 & 25 \\
\hline $8 * * *$ & 15 & 100 & 0 & 0 & 12 & 42 & 58 & 0 \\
\hline $14^{\mathrm{ns}}$ & 15 & 100 & 0 & 0 & 13 & 100 & 0 & 0 \\
\hline \multicolumn{9}{|l|}{ II } \\
\hline $6 * * *$ & 16 & 100 & 0 & 0 & 15 & 26 & 67 & 7 \\
\hline $8 * * *$ & 16 & 100 & 0 & 0 & 16 & 50 & 50 & 0 \\
\hline $14^{\mathrm{ns}}$ & 15 & 100 & 0 & 0 & 15 & 100 & 0 & 0 \\
\hline \multicolumn{9}{|l|}{ III } \\
\hline $6 * * *$ & 15 & 73 & 27 & 0 & 16 & 6 & 69 & 25 \\
\hline $8 * * *$ & 14 & 100 & 0 & 0 & 15 & 40 & 60 & 0 \\
\hline $14^{\mathrm{ns}}$ & 18 & 100 & 0 & 0 & 15 & 100 & 0 & 0 \\
\hline
\end{tabular}

${ }^{a}$ Wheat seedlings were inoculated with TriMV-green fluorescent protein (GFP) or buffer at the single-leaf stage, followed with WSMV-red fluorescent protein (RFP) at 10 days postinoculation. Inoc $(n)=$ number of plants inoculated.

b In three experiments (Exp), WSMV-RFP infections on TriMV-GFPinfected and buffer-inoculated wheat were compared by $\chi^{2}$ analysis. Asterisks (***) indicate statistically significant at $P<0.01$, ns $=$ not statistically significant, and dpsvi = days postsecondary virus inoculation. 
(Fig. 2A). Similarly, genomic RNA copies of wild-type and GFP-tagged TriMV accumulated in doubly infected wheat by statistically significant 2.6- to 9.1-fold and 2.8- to 10.0-fold, respectively, compared with singly infected plants at $9,14,21$, and 28 dpi (Fig. 2B). These data revealed that coinfection of wheat by fluorescent protein-tagged WSMV and TriMV resulted in significantly increased accumulation of individual viruses, similar to that of wild-type viruses. However, genomic RNAs of the fluorescent protein-tagged WSMV and TriMV accumulated at slightly reduced levels in wheat compared with the respective wild-type viruses.

In wheat coinfected by wild-type or fluorescent proteintagged viruses, $\mathrm{CP}$ of WSMV and TriMV accumulated at 1.6- to 2.6-fold and 1.7- to 9.0-fold higher than singly infected plants, respectively, at 9, 14, 21, and $28 \mathrm{dpi}$ (Fig. 2C and D). As observed with genomic RNA copies, CPs of fluorescent proteintagged WSMV and TriMV also accumulated at slightly reduced levels in singly and doubly infected wheat compared with the respective wild-type viruses. Collectively, these data revealed that fluorescent protein-tagged WSMV and TriMV interact synergistically in coinfected wheat with increased accumulation of both viruses, similar to that of wild-type viruses.

\section{Systemic infection of wheat by WSMV or TriMV affected the establishment of local infection by the other SIP virus.}

Successful establishment of local infection is a prerequisite for systemic infection in most virus-plant combinations. We examined the effect of systemic infection of wheat by one of the SIP viruses, WSMV-RFP or TriMV-GFP, on the establishment of local foci by the other SIP virus. Wheat seedlings were inoculated at the single-leaf stage with WSMV-RFP or TriMVGFP, followed by inoculation of symptomatic third leaves with TriMV-GFP or WSMV-RFP, respectively. As a control, buffer-inoculated plants were inoculated with TriMV-GFP or WSMV-RFP.

In three independent experiments, WSMV-RFP elicited 16.6 to 39.5 foci per leaf on wheat leaves preinfected with TriMVGFP compared with 32.1 to 54.7 foci per leaf on bufferinoculated wheat (Fig. 3). TriMV-GFP elicited 15.7 to 32.8 foci per leaf on WSMV-RFP-infected wheat compared with 28.3 to 52.9 foci per leaf on wheat preinoculated with buffer (Fig. 3). These data suggest that prior infection of wheat by an SIP virus inhibited the development of local foci by the other SIP virus. We next examined the effect of prior infection of wheat by an SIP virus on cell-to-cell movement of the other SIP virus by measuring the size of local foci. In three independent experiments, WSMV-RFP elicited $0.52-$ to $1.09-\mathrm{mm}^{2}$ sized foci on wheat preinfected with TriMV-GFP compared with 1.09- to $1.73-\mathrm{mm}^{2}$ foci on wheat preinoculated with buffer (Fig. 3). TriMV-GFP elicited 0.50 - to $0.95-\mathrm{mm}^{2}$ sized foci on wheat leaves preinfected with WSMV-RFP compared with 0.84- to $1.49-\mathrm{mm}^{2}$ on buffer-inoculated wheat in three independent experiments (Fig. 3). These data indicate that preinfection of wheat by a primary SIP virus inhibited cell-to-cell movement of the other SIP virus statistically significantly at the site of infection. Taken together, these data suggest that preinfection of wheat by an SIP virus interfered with the initiation and establishment of local foci by the respective secondary SIP virus.

\section{Prior infection of wheat by TriMV facilitated accelerated long-distance movement of WSMV.}

The effect of prior infection of wheat by a primary SIP virus on the establishment of systemic infection by a secondary SIP virus was examined using TriMV-GFP and WSMV-RFP as primary and secondary SIP viruses, respectively. Third symptomatic leaves of wheat infected by TriMV-GFP were inoculated with crude sap of WSMV-RFP and observed for systemic infection of WSMV-RFP in upper uninoculated leaves under a Zeiss Stereo Discovery V12 fluorescence dissecting microscope (Carl Zeiss MicroImaging, Inc., New York) at 6, 8, 14 , and 21 days postsecondary virus inoculation (dpsvi). In three independent experiments, at 6 dpsvi, WSMV-RFP infected 73 to $100 \%$ of wheat preinfected with TriMV-GFP with RFP covering most of the leaf lamina, 6 to $27 \%$ of plants systemically infected had several RFP foci per leaf, and 0 to $13 \%$ of plants failed to infect systemically (Fig. 4A; Table 1). In contrast, at 6 dpsvi, WSMV-RFP systemically infected only 0 to $26 \%$ of buffer-inoculated wheat with RFP covering throughout the leaf lamina, 67 to $75 \%$ of plants were infected with several RFP foci per leaf, and 7 to $25 \%$ of plants failed to infect systemically (Fig. 4A; Table 1). At 8 dpsvi, all of the wheat plants preinfected with TriMV-GFP were systemically infected by WSMV-RFP with strong RFP expression compared with 40 to $50 \%$ of plants with strong RFP expression and 50 to $60 \%$ of plants with moderate expression of RFP in bufferinoculated wheat (Fig. 4B; Table 1). At 14 and 21 dpsvi, WSMV-RFP infected systemically all TriMV-GFP-infected or buffer-inoculated wheat; however, brighter RFP expression was observed in wheat preinfected with TriMV-GFP compared with buffer-inoculated wheat (Fig. 4C). These data suggest that prior infection of wheat by TriMV-GFP facilitated statistically

Table 2. Effect of Triticum mosaic virus (TriMV) prior infection on Wheat streak mosaic virus (WSMV) accumulation in wheat ${ }^{\mathrm{a}}$

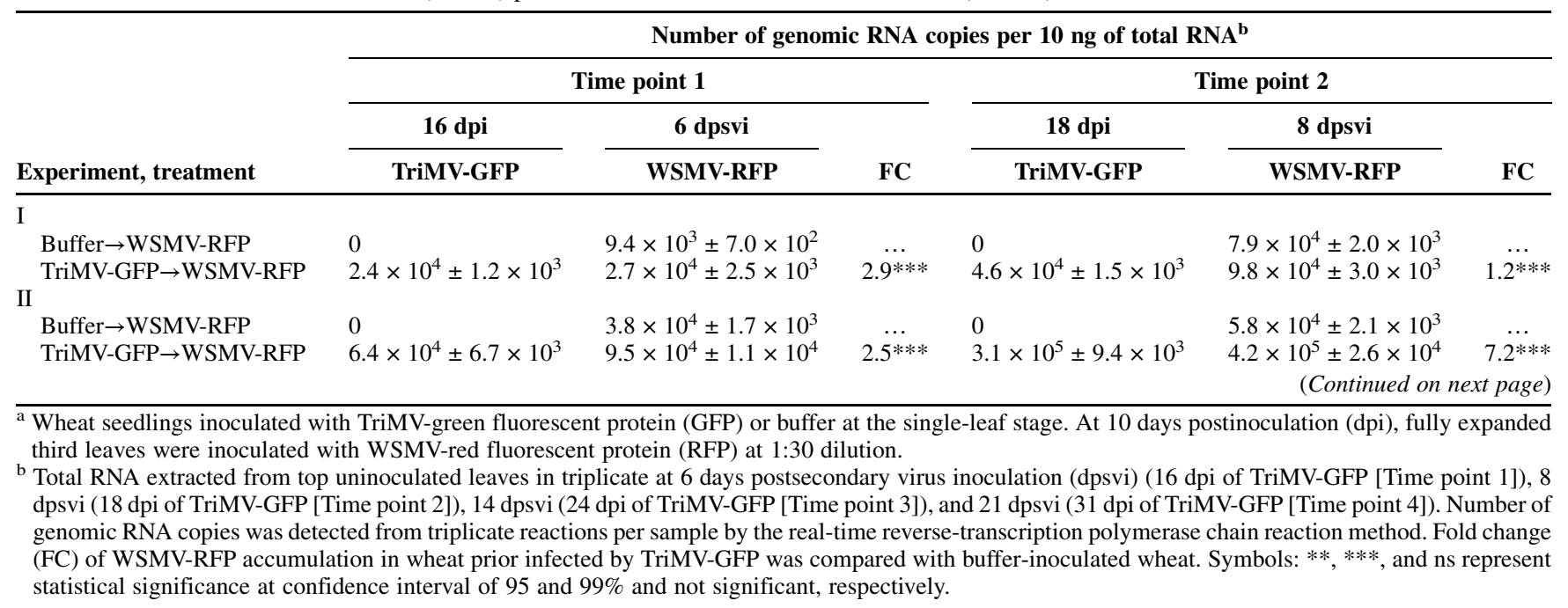


significant accelerated long-distance movement of WSMVRFP compared with buffer-inoculated plants.

Accumulation of genomic RNA copies of WSMV was examined in wheat by real-time reverse-transcription (RT)-PCR from two independent experiments. WSMV genomic RNA copies accumulated statistically significantly at 2.5- to 2.9-, 1.2- to 7.2-, 2.1- to 3.6-, and 1.0- to 4.9-fold in wheat preinfected with TriMV compared with those in buffer-inoculated wheat at 6, 8, 14, and 21 dpsvi, respectively (Table 2). These data confirm that preinfection of wheat by TriMV-GFP facilitated increased accumulation of WSMV genomic RNA. Infection of wheat by TriMV-GFP was confirmed by observing increased accumulation of genomic RNA copies of TriMV at four time points (Table 2). The effect of preinfection of wheat with TriMV-GFP on systemic infection of WSMV-RFP was further examined by Western immunoblot assay for $\mathrm{CP}$ accumulation (Fig. 5). WSMV CP accumulated in wheat preinfected with TriMV-GFP at 2.5-, 1.6-, 2.0-, and 2.0-fold compared with that of in buffer-inoculated wheat at $6,8,14$, and 21 dpsvi, respectively (Fig. 5, top blot). At all time points examined, TriMV CP accumulated at significant levels (Fig. 5, lower blot). These data indicate that prior infection of TriMV facilitated enhanced genomic RNA accumulation and long-distance movement of WSMV compared with those in buffer-inoculated wheat.

\section{Prior infection of wheat by WSMV delayed long-distance movement of TriMV \\ during early stages of synergistic interaction.}

We next examined effects of prior infection of wheat by WSMV on the establishment of systemic infection by TriMV. Third leaves of WSMV-RFP-infected wheat were inoculated with TriMV-GFP, and systemic infection of wheat by TriMVGFP was examined at $6,8,14$, and 21 dpsvi under a fluorescent microscope. In three independent experiments, at 6 dpsvi, TriMV-GFP systemically infected 6 to $23 \%$ of WSMV-RFPinfected wheat with GFP covering most of the leaf lamina, 13 to $53 \%$ of plants were systemically infected with several GFP foci per leaf, and 42 to $81 \%$ of plants failed to express GFP at detectable levels (Fig. 6A; Table 3). In contrast, TriMV-GFP systemically infected 79 to $94 \%$ of buffer-inoculated plants with GFP expression covering most of the leaf lamina and 0 to $21 \%$ of plants with several GFP foci per leaf, and only 0 to $8 \%$ of plants failed to infect (Fig. 6A; Table 3). At 8 dpsvi, TriMVGFP systemically infected 59 to $70 \%$ of WSMV-RFP-infected wheat with GFP covering most of the leaf lamina compared with $100 \%$ of infection in buffer-inoculated plants (Table 3 ). At 14 dpsvi, all WSMV-RFP-infected and buffer-inoculated wheat were systemically infected by TriMV-GFP (Fig. 6C; Table 3); however, stronger GFP fluorescence was observed in WSMV-RFP-infected wheat compared with buffer-inoculated wheat. These data indicate that prior infection of wheat by
WSMV-RFP interfered with long-distance movement of TriMV during early stages of synergistic interaction.

Interaction of TriMV with WSMV during early stages of synergistic interaction was further examined by quantifying genomic RNA copies of TriMV from WSMV-RFP-infected or buffer-inoculated wheat (Table 4). In two independent experiments, TriMV genomic RNA copies accumulated at statistically significant levels at only 0.12 - to 0.29 -fold and 0.72 - to 1.8-fold at 6 and 8 dpsvi, respectively, in WSMV-RFP-infected wheat compared with those in buffer-inoculated plants. However, accumulation of TriMV rapidly increased by 14- to 30-fold and 1.3- to 4.1-fold in WSMV-RFP-infected wheat compared with those in buffer-inoculated plants at 14 and 21

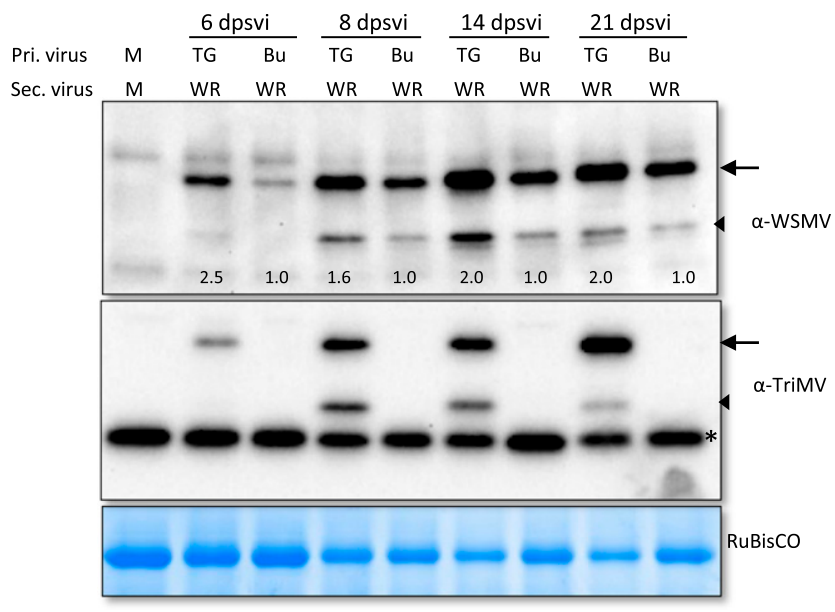

Fig. 5. Wheat infection by Triticum mosaic virus (TriMV)-green fluorescent protein (GFP) enabled increased accumulation of Wheat streak mosaic virus (WSMV)-red fluorescent protein (RFP). Western blot analysis of total proteins was performed from wheat infected by the primary virus (TriMVGFP or buffer) followed by the secondary virus (WSMV-RFP) at 6, 8, 14, and 21 days postsecondary virus inoculation (dpsvi). Wheat seedlings were inoculated with the primary virus at the single-leaf stage followed by the secondary virus at 10 days postprimary virus inoculation. Western blots were probed with polyclonal antibodies against WSMV virions (top blot) and TriMV coat protein (CP) (bottom blot). Numbers at the bottom of immunoblot with WSMV antibodies indicate fold-increase in accumulation of WSMV CP-specific major protein (secondary virus) in wheat preinfected with TriMV-GFP compared with that of buffer-inoculated wheat at $6,8,14$, and 21 dpsvi. Coomassie brilliant blue stained sodium dodecyl sulfate polyacrylamide gel electrophoresis gel shows wheat RuBisCO protein for the amount of total protein loaded per well. The full-length $\mathrm{CP}$ and a truncated minor CP that reacted positively with WSMV or TriMV antibodies are indicated with arrows and arrowheads, respectively. A wheat protein that nonspecifically reacted with TriMV polyclonal antibodies is indicated with an asterisk. Western blot analysis of total proteins with WSMV and TriMV polyclonal antibodies was performed from three independent experiments, and representative blots from one experiment are presented. WR $=$ WSMV-RFP, TG $=$ TriMVGFP, and $\mathrm{Bu}=$ buffer.

Table 2. (Continued from previous page)

\begin{tabular}{|c|c|c|c|c|c|}
\hline \multicolumn{6}{|c|}{ Number of genomic RNA copies per 10 ng of total RNA } \\
\hline \multicolumn{3}{|c|}{ Time point 3} & \multicolumn{3}{|c|}{ Time point 4} \\
\hline 24 dpi & 14 dpsvi & & 31 dpi & 21 dpsvi & \\
\hline TriMV-GFP & WSMV-RFP & $\mathbf{F C}$ & TriMV-GFP & WSMV-RFP & FC \\
\hline 0 & $1.6 \times 10^{5} \pm 3.8 \times 10^{3}$ & $\ldots$ & 0 & $8.7 \times 10^{4} \pm 6.8 \times 10^{3}$ & $\ldots$ \\
\hline $7.0 \times 10^{5} \pm 4.8 \times 10^{4}$ & $5.8 \times 10^{5} \pm 1.2 \times 10^{4}$ & $3.6^{* * * *}$ & $1.3 \times 10^{6} \pm 2.6 \times 10^{4}$ & $4.3 \times 10^{5} \pm 8.2 \times 10^{3}$ & $4.9^{* * *}$ \\
\hline 0 & $3.2 \times 10^{5} \pm 1.7 \times 10^{4}$ & $\ldots$ & 0 & $3.3 \times 10^{4} \pm 1.1 \times 10^{3}$ & \\
\hline $3.5 \times 10^{5} \pm 5.2 \times 10^{4}$ & $6.9 \times 10^{5} \pm 1.0 \times 10^{5}$ & $2.1 * *$ & $2.7 \times 10^{4} \pm 2.8 \times 10^{3}$ & $3.3 \times 10^{4} \pm 3.7 \times 10^{3}$ & $1.0^{\mathrm{ns}}$ \\
\hline
\end{tabular}




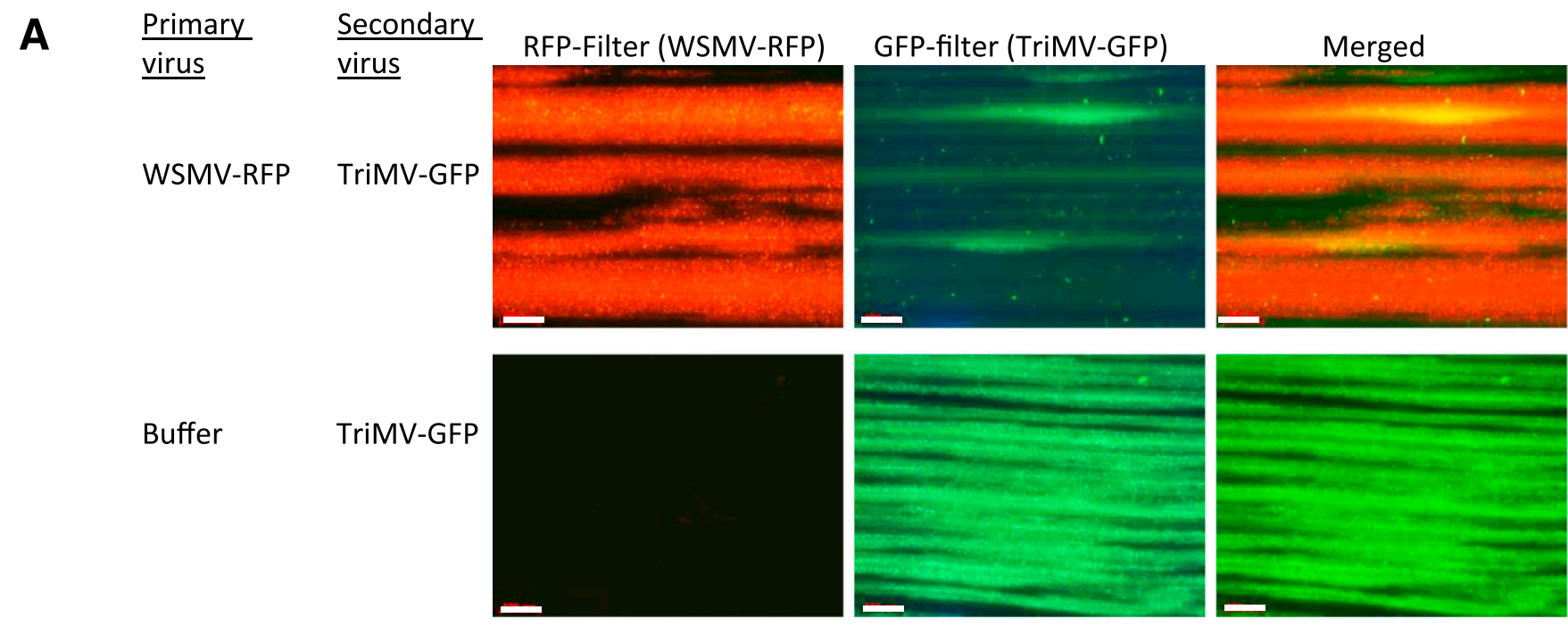

B

B

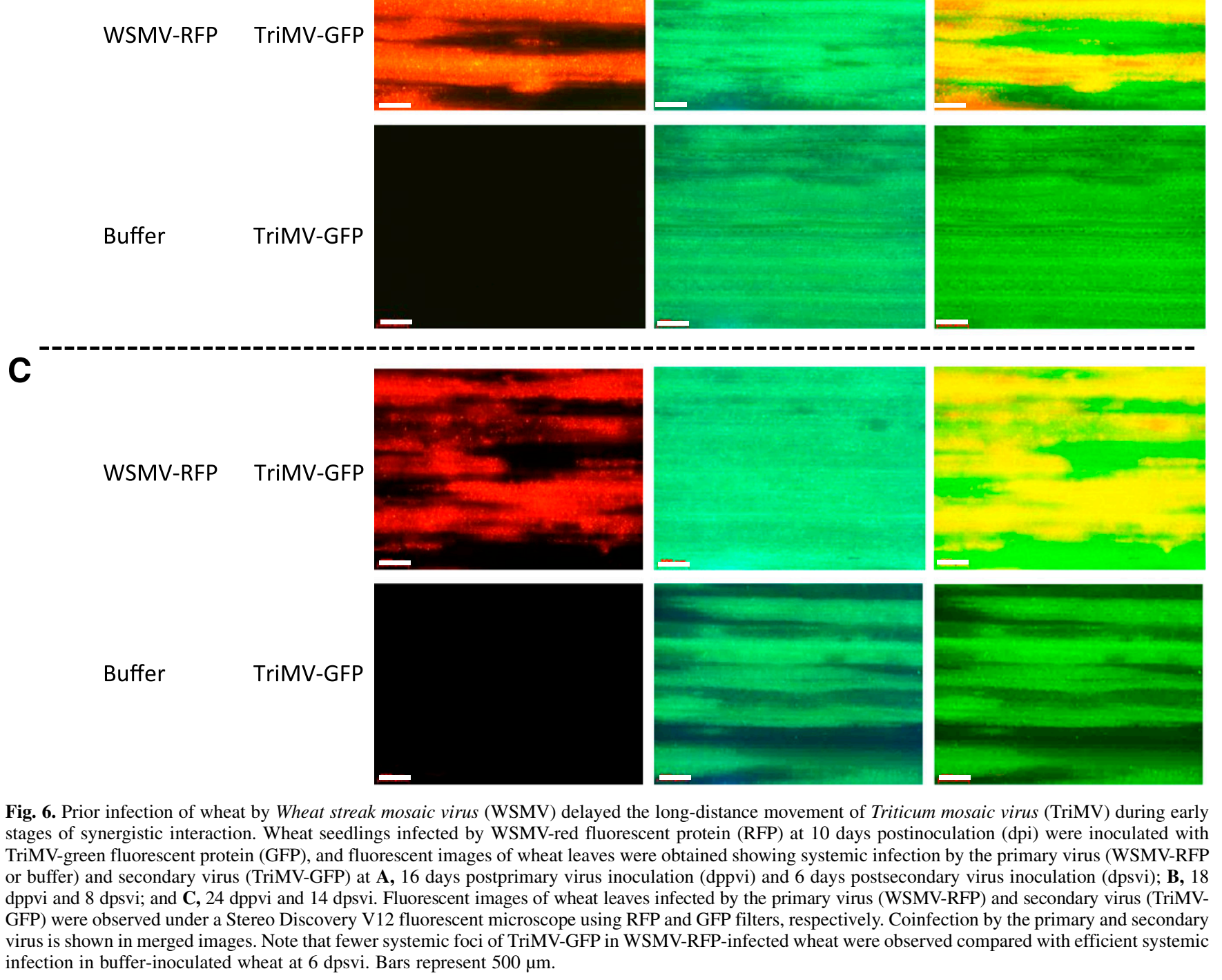


dpsvi, respectively (Table 4). Accumulation of WSMV genomic RNA copies increased substantially after the establishment of TriMV-GFP infection, most likely due to establishment of synergistic interaction. Additionally, the effect of prior WSMV infection on TriMV systemic infection in wheat was examined by Western immunoblot analyses. TriMV $\mathrm{CP}$ accumulated only at 0.3 - and 0.8 -fold at 6 and 8 dpsvi, respectively, in WSMV-RFP-infected wheat compared with those in buffer-inoculated plants (Fig. 7, top blot). However, accumulation of TriMV CP increased rapidly to 5.2- and 3.1fold at 14 and 21 dpsvi, respectively, in WSMV-RFP-infected wheat compared with those in buffer-inoculated plants (Fig. 7, top blot). WSMV CP accumulated efficiently at all time points examined (Fig. 7, lower blot). Collectively, these data indicate that prior infection of wheat by WSMV negatively interfered with long-distance movement of TriMV during early stages of synergistic interaction.

\section{TriMV dominates early on for systemic infection} in simultaneously inoculated wheat compared with WSMV.

The above data indicated that prior infection of wheat by WSMV or TriMV displayed contrasting effects on longdistance movement of the other SIP virus. To further examine this phenomenon, the third leaf of wheat was coinoculated with crude sap of WSMV-RFP and TriMV-GFP at 1:30 dilution. Systemic infection of wheat by WSMV-RFP and TriMV-GFP was examined for the expression of fluorescence proteins and accumulation of viral genomic RNA copies at $6,8,14$, and $21 \mathrm{dpi}$. In three independent experiments, at 6 dpi, TriMV-GFP infected 77 to $91 \%$ of plants with strong GFP expression, 9 to $16 \%$ plants with moderate GFP expression, and 0 to $8 \%$ of plants with no detectable GFP expression (Fig. 8A; Table 5). In contrast, WSMV-RFP infected only 0 to $36 \%$ of plants with strong RFP expression, 58 to $67 \%$ of plants with weak RFP expression, and 0 to $42 \%$ of plants with no detectable RFP expression (Fig. 8A; Table 5). At 8 dpi, TriMV-GFP infected $100 \%$ of plants with strong GFP expression. Conversely, WSMV-RFP infected 46 to $63 \%$ of plants with strong RFP expression and 37 to $54 \%$ of plants with weak RFP expression (Fig. 8A; Table 5). At 8 dpi, though both WSMV-RFP and TriMV-GFP infected $100 \%$ of plants, TriMV-GFP infected wheat with stronger GFP expression compared with that of RFP expression for WSMV-RFP-infection. At 14 and $21 \mathrm{dpi}$, both TriMV-GFP and WSMV-RFP infected $100 \%$ of wheat with strong fluorescent protein expression (Fig. 8A).

Accumulation of genomic RNA copies of WSMV and TriMV was determined by real-time RT-PCR from total RNA isolated from wheat coinoculated with WSMV-RFP and TriMV-GFP. TriMV genomic RNA copies accumulated efficiently at statistically significant 6.2-, 4.5-, and 2.2-fold higher than those of WSMV at 6, 8 and 14 dpi, respectively (Fig. 8B). At $21 \mathrm{dpi}$, TriMV-GFP accumulated at 0.7 -fold of WSMV. Taken together, these data suggest that TriMV but not WSMV could efficiently move long distance during early stages of coinfection in wheat.

\section{DISCUSSION}

In this study, the effect of prior infection of wheat by either of the interacting viruses (WSMV or TriMV) on early stages of synergistic interaction upon superinfection by another interacting partner virus was examined using fluorescent proteintagged viruses. We found that prior infection of wheat by WSMV or TriMV affected the number and size of local foci elicited by the other SIP virus compared with those on buffer-inoculated wheat leaves. However, prior infection of wheat by WSMV or TriMV differentially affected the longdistance movement of the other SIP virus during early stages of synergistic interaction. There are numerous examples of asymmetry of virus-virus interactions resulting in superinfection exclusion or cross protection (Mascia and Gallitelli 2016; Syller and Grupa 2016), and our results demonstrate that interactions between synergistically interacting viruses also can be asymmetric. Future research will be required to determine whether this is a widespread phenomenon among other synergistically interacting viruses as well.

We previously reported that wheat curl mite-transmitted WSMV and TriMV synergistically interact in wheat with increased concentration of both viruses (Tatineni et al. 2010). Availability of fluorescent protein-tagged WSMV (WSMVRFP) (Tatineni et al. 2016) and TriMV (TriMV-GFP) (Tatineni et al. 2015) and their efficient mechanical transmission to wheat facilitated the examination of early events in the establishment of synergistic interaction between WSMV and TriMV in wheat. Insertion of foreign sequences into viral genomes could affect viral pathogenicity or synergistic interaction (Rabindran and

Table 3. Effect of Wheat streak mosaic virus (WSMV) prior infection on Triticum mosaic virus (TriMV) systemic infection in wheat ${ }^{\mathrm{a}}$

\begin{tabular}{|c|c|c|c|c|c|c|c|c|}
\hline \multirow[b]{4}{*}{ Exp, dpsvi ${ }^{b}$} & \multicolumn{8}{|c|}{ Systemic infection of TriMV-GFP } \\
\hline & \multicolumn{4}{|c|}{ In WSMV-RFP-infected wheat } & \multicolumn{4}{|c|}{ In buffer-inoculated wheat } \\
\hline & \multirow[b]{2}{*}{ Inoc $(n)$} & \multicolumn{3}{|c|}{ Plants with GFP expression (\%) } & \multirow[b]{2}{*}{ Inoc $(n)$} & \multicolumn{3}{|c|}{ Plants with GFP expression (\%) } \\
\hline & & Strong & Weak & No GFP & & Strong & Weak & No GFP \\
\hline \multicolumn{9}{|l|}{ I } \\
\hline $6 * * *$ & 17 & 6 & 13 & 81 & 12 & 92 & 0 & 8 \\
\hline $8 * * *$ & 17 & 59 & 41 & 0 & 12 & 100 & 0 & 0 \\
\hline $14^{\mathrm{ns}}$ & 17 & 100 & 0 & 0 & 12 & 100 & 0 & 0 \\
\hline \multicolumn{9}{|l|}{ II } \\
\hline $6 * * *$ & 16 & 5 & 53 & 42 & 14 & 79 & 21 & 8 \\
\hline $8 * * *$ & 16 & 63 & 31 & 6 & 17 & 100 & 0 & 0 \\
\hline $14^{\mathrm{ns}}$ & 13 & 100 & 0 & 0 & 15 & 100 & 0 & 0 \\
\hline \multicolumn{9}{|l|}{ III } \\
\hline $6 * * *$ & 13 & 23 & 31 & 46 & 11 & 94 & 6 & 0 \\
\hline $8 * * *$ & 15 & 70 & 25 & 5 & 14 & 100 & 0 & 0 \\
\hline $14^{\mathrm{ns}}$ & 14 & 100 & 0 & 0 & 14 & 100 & 0 & 0 \\
\hline
\end{tabular}

${ }^{a}$ Wheat seedlings were inoculated with WSMV-red fluorescent protein (RFP) or buffer at the single-leaf stage, followed with TriMV-green fluorescent protein $(\mathrm{GFP})$ at 10 days postinoculation. Inoc $(n)=$ number of plants inoculated.

$\mathrm{b}$ In three experiments (Exp), TriMV-GFP infections on WSMV-RFP-infected and buffer-inoculated wheat were compared by $\chi^{2}$ analysis. Asterisks (***) indicate statistically significant at $P<0.01$, ns $=$ not statistically significant, and dpsvi $=$ days postsecondary virus inoculation. 
Dawson 2001). However, we found that WSMV-RFP and TriMV-GFP elicited symptoms similar to those of the respective wild-type viruses, with a slight delay in the onset of systemic symptoms (Tatineni et al. 2011a, 2015, 2016). In this study, we found that coinfection of wheat by WSMV-RFP and TriMV-GFP resulted in increased symptom phenotypes with enhanced accumulation of both viruses compared with singly infected fluorescent protein-tagged viruses. These data indicated that fluorescent protein-tagged WSMV and TriMV interact synergistically in a manner similar to the wild-type viruses (Tatineni et al. 2010). Thus, the availability of synergistically interacting fluorescent protein-tagged WSMV and TriMV with stably maintained fluorescent protein open reading frames in their genomes (Tatineni et al. 2011a, 2015) provides an excellent system to study the early events in synergistic interaction.

It is unlikely that the SIP viruses infect host plants simultaneously to induce disease synergism under field conditions. Indeed, coinfection of crop plants by multiple viruses could be due to infection of plants by unrelated viruses at different time points. To mimic naturally occurring synergistic interaction, the effect of preinfection of wheat by WSMV-RFP or TriMV-GFP on the establishment of local infection by the other SIP virus was examined. We found that prior infection of wheat by WSMV-RFP or TriMV-GFP significantly affected the number and size of local foci of the secondary SIP virus compared with those on buffer-inoculated wheat. These data suggest that prior infection of wheat by a primary SIP virus has an adverse effect on the initiation of local infection and subsequent cell-to-cell movement by the secondary SIP virus. The observed negative effects of a primary SIP virus on local infection of a secondary SIP virus could be due to the prior infection limiting the resources available for the establishment of initial infection by the secondary virus.

In synergistic interactions, coinfection of plants by unrelated viruses generally elicits acute disease, with increased concentration of one or both interacting viruses (Mascia and Gallitelli 2016; Syller 2012). However, the effect of prior infection of plants by either interacting virus on the establishment of systemic infection by the secondary SIP virus is poorly understood. Does prior infection of plants by an SIP virus affect the early stages of establishment of synergistic interaction with another SIP virus? In this study, we found that prior infection of wheat by TriMV accelerated systemic infection of WSMV compared with buffer-inoculated plants, suggesting that WSMV benefits from prior infection of wheat by TriMV for long-distance movement and replication. In contrast, prior infection of wheat by WSMV negatively affected the establishment of systemic infection of TriMV during early stages of synergistic interaction compared with those in buffer-inoculated wheat. TriMV efficiently infected buffer-inoculated wheat with increased accumulation of genomic RNAs during early stages of infection at 6 dpsvi. However, prior infection of wheat by WSMV resulted in a rapid increase in accumulation of TriMV during later stages of synergistic interaction at 14 and 21 dpsvi. Collectively, these data suggest that prior infection of wheat by WSMV negatively affects the establishment of TriMV infection during early stages of synergistic interaction, whereas TriMV benefits from WSMV infection during later stages. It is not clear why prior infection of wheat by WSMV or TriMV differentially affected the early stages of synergistic interaction. It is possible that nascent WSMV proteins efficiently recognize TriMV proteins for protein-protein interactions in TriMV-infected plants, leading to rapid long-distance movement and replication during early stages of synergistic interaction. However, lack of such interactions in buffer-inoculated wheat might have facilitated slower replication and long-distance movement.

Viruses are obligate parasites that depend on the host metabolic machinery for replication and movement (Nelson and Citovsky 2005). Depletion of wheat resources in WSMV-infected plants due to the virus's relatively severe symptom phenotype may have contributed to slower systemic infection of TriMV in WSMVinfected wheat during early stages of infection. It is also possible that slow interaction of TriMV proteins with WSMV proteins may have contributed to delayed synergistic interaction between these viruses. However, during late stages of infection, TriMV proteins may have established an efficient interaction with WSMV proteins, thus facilitating increased TriMV replication and long-distance movement. Our data suggest that an asymmetry in synergistic interaction between WSMV and TriMV depends on the order of infection of wheat by the SIP viruses. Recently, both antagonistic and synergistic interactions were observed between unrelated Papaya ringspot virus and Papaya mosaic virus, depending on their order of infection (Chávez-Calvillo et al. 2016). However, delayed onset of systemic symptoms by TriMV in WSMV-infected wheat may not be called antagonistic because prior infection of WSMV affected only the early stages of synergistic interaction but not the later stages.

Differential effects of the order of primary infection by WSMV and TriMV on early stages of systemic infections by respective SIP viruses is most likely not due to differential

Table 4. Effect of Wheat streak mosaic virus (WSMV) prior infection on Triticum mosaic virus (TriMV) accumulation in wheat ${ }^{\mathrm{a}}$

\begin{tabular}{|c|c|c|c|c|c|c|}
\hline \multirow[b]{4}{*}{ Experiment, treatment } & \multicolumn{6}{|c|}{ Number of genomic RNA copies per 10 ng of total $R N A^{b}$} \\
\hline & \multicolumn{3}{|c|}{ Time point 1} & \multicolumn{3}{|c|}{ Time point 2} \\
\hline & 16 dpi & 6 dpsvi & & 18 dpi & 8 dpsvi & \\
\hline & WSMV-RFP & TriMV-GFP & FC & WSMV-RFP & TriMV-GFP & FC \\
\hline \multicolumn{7}{|l|}{ I } \\
\hline Buffer $\rightarrow$ TriMV-GFP & 0 & $2.6 \times 10^{5} \pm 7.1 \times 10^{3}$ & & 0 & $3.1 \times 10^{5} \pm 3.3 \times 10^{4}$ & \\
\hline WSMV-RFP $\rightarrow$ TriMV-GFP & $4.9 \times 10^{4} \pm 1.8 \times 10^{3}$ & $3.2 \times 10^{4} \pm 2.6 \times 10^{3}$ & $0.12 * * *$ & $3.8 \times 10^{5} \pm 1.1 \times 10^{4}$ & $2.2 \times 10^{5} \pm 2.1 \times 10^{4}$ & $0.72^{\text {ns }}$ \\
\hline \multicolumn{7}{|l|}{ II } \\
\hline $\begin{array}{l}\text { Buffer } \rightarrow \text { TriMV-GFP } \\
\text { WSMV-RFP } \rightarrow \text { TriMV-GFP }\end{array}$ & $\begin{array}{l}0 \\
7.8 \times 10^{4} \pm 3.3 \times 10^{3}\end{array}$ & $\begin{array}{l}9.3 \times 10^{4} \pm 2.3 \times 10^{4} \\
2.7 \times 10^{4} \pm 6.2 \times 10^{3}\end{array}$ & $\begin{array}{c}\ldots \\
0.29 * *\end{array}$ & $\begin{array}{l}0 \\
1.7 \times 10^{5} \pm 1.2 \times 10^{4}\end{array}$ & $\begin{array}{l}3.4 \times 10^{5} \pm 1.9 \times 10^{4} \\
6.0 \times 10^{5} \pm 3.1 \times 10^{4}\end{array}$ & $\begin{array}{c}\ldots \\
1.8 * *\end{array}$ \\
\hline \multicolumn{7}{|c|}{ (Continued on next page) } \\
\hline Wheat seedlings inoculate & VSMV-red fluores & tein (RFP) at the $s$ & af stag & 10 days postinocul & pi), the top fully ex & \\
\hline $\begin{array}{l}\text { b Total RNA extracted from to } \\
\text { dpsvi (18 dpi of WSMV-RFP } \\
\text { of genomic RNA copies was } \\
\text { change (FC) of TriMV-GFP }\end{array}$ & $\begin{array}{l}\text { me point 2]), } 14 \mathrm{dps} \\
\text { tected from triplicate } \\
\text { umulation in wheat }\end{array}$ & $\begin{array}{l}\text { cate at } 6 \text { days postsec } \\
\text { dpi of WSMV-RFP [] } \\
\text { tions per sample by th } \\
\text { infected by WSMV-R }\end{array}$ & $\begin{array}{l}\text { lary viru } \\
\text { point } 3 \\
\text { eal-time }\end{array}$ & $\begin{array}{l}\text { oculation (dpsvi) }(16 \\
\text { d } 21 \text { dpsvi ( } 31 \text { dpi of } \\
\text { erse transcription poly } \\
\text { ed with buffer-inocula }\end{array}$ & $\begin{array}{l}\text { of WSMV-RFP [Time } \mathrm{p} \\
\text { MV-RFP [Time point 4] } \\
\text { ase chain reaction meth } \\
\text { wheat. Symbols: **,** }\end{array}$ & $\begin{array}{l}\text { nt 1]), } 8 \\
\text { Number } \\
\text { d. Fold }\end{array}$ \\
\hline
\end{tabular}


number of local foci elicited on buffer-inoculated and WSMV- or TriMV-infected wheat. Although WSMV elicited significantly more and larger foci on buffer-inoculated wheat compared with those on TriMV-infected wheat, WSMV facilitated accelerated long-distance movement in TriMV-infected wheat compared with that in buffer-inoculated plants. These data suggest that local foci elicited by a secondary virus do not appear to play a crucial role in differential effects of WSMV and TriMV on the establishment of systemic infection by the corresponding secondary virus.

A severe symptom phenotype of synergistic interactions is perhaps the result of increased accumulation of one or both interacting viruses. Our data suggest that preinfection of wheat by either SIP virus has no significant advantage on the establishment of local infection by the secondary SIP virus. Preinfection of wheat by WSMV negatively affected the early stages of synergistic interaction with TriMV, which could delay the development of severe symptoms by a few days. In contrast, infection of wheat by TriMV facilitated rapid onset of WSMV systemic infection, eliciting more severe disease compared with TriMV infection on WSMV-infected wheat. Collectively, our data suggest that neither WSMV nor TriMV benefits from wheat preinfection by the respective SIP virus on the establishment of local infection. The present study also revealed that WSMV benefited from prior infection of wheat by TriMV during early stages of systemic infection but prior infection of wheat by WSMV negatively affected TriMV systemic infection. Nevertheless, both viruses benefited from each other during late stages of synergistic interaction, with an acute symptom phenotype and increased accumulation of both interacting viruses.

\section{MATERIALS AND METHODS}

\section{Viruses.}

In vitro transcripts from pSP6-WSMV (Choi et al. 1999) and pTriMV (Tatineni et al. 2015) were inoculated onto wheat seedlings at the single-leaf stage to obtain WSMV isolate Sidney 81 and TriMV isolate Nebraska, respectively. WSMV-RFP and TriMV-GFP were obtained by inoculating in vitro transcripts of pSP6-WSMV-RFP-6K1/CI(7aa) (Tatineni et al. 2016) and pTriMV-GFP-NIb/CP(9aa) (Tatineni et al. 2015), respectively. WSMV-, TriMV-, WSMV-RFP-, or TriMV-GFP-infected wheat leaves at $14 \mathrm{dpi}$ were stored at $-80^{\circ} \mathrm{C}$ for future inoculation of wheat seedlings for synergistic interaction studies.

\section{Synergistic interaction studies between fluorescent protein-tagged WSMV and TriMV.}

Young wheat leaves infected with in vitro transcripts of WSMV, TriMV, WSMV-RFP, or TriMV-GFP at 14 dpi were ground in a mortar and pestle in $20 \mathrm{mM}$ sodium phosphate buffer, $\mathrm{pH} 7.0$ (inoculation buffer) at 1:10 (wt/vol) dilution. The inoculum of individual viruses was mixed with an equal volume of inoculation buffer to obtain 1:20 dilution. Equal volumes of 1:10 dilution of WSMV and TriMV or WSMV-RFP and TriMV-GFP were mixed to obtain WSMV+TriMV and WSMV-RFP+TriMV-GFP, respectively, with a final concentration of 1:20 (wt/vol) dilution. Carborundum dusted Tomahawk wheat seedlings at the singleleaf stage were inoculated with individual (WSMV, TriMV, WSMV-RFP, or TriMV-GFP) or mixed (WSMV+TriMV or WSMV-RFP+TriMV-GFP) viruses. Inoculated wheat seedlings were incubated in a growth chamber (Conviron, Pembina, ND) at $23^{\circ} \mathrm{C}$ (maximum) and $20^{\circ} \mathrm{C}$ (minimum) with $14 \mathrm{~h}$ of light $\left(210 \mu \mathrm{mol} \mathrm{m} \mathrm{m}^{-2} \mathrm{~s}^{-1}\right)$. The development of local foci and systemic infection by fluorescent protein-tagged viruses was observed under a Stereo Discovery V12 fluorescence dissecting microscope (Carl Zeiss MicroImaging, Inc.) using a narrow-band filter set of RFP or GFP, as described by Tatineni et al. (2016). The

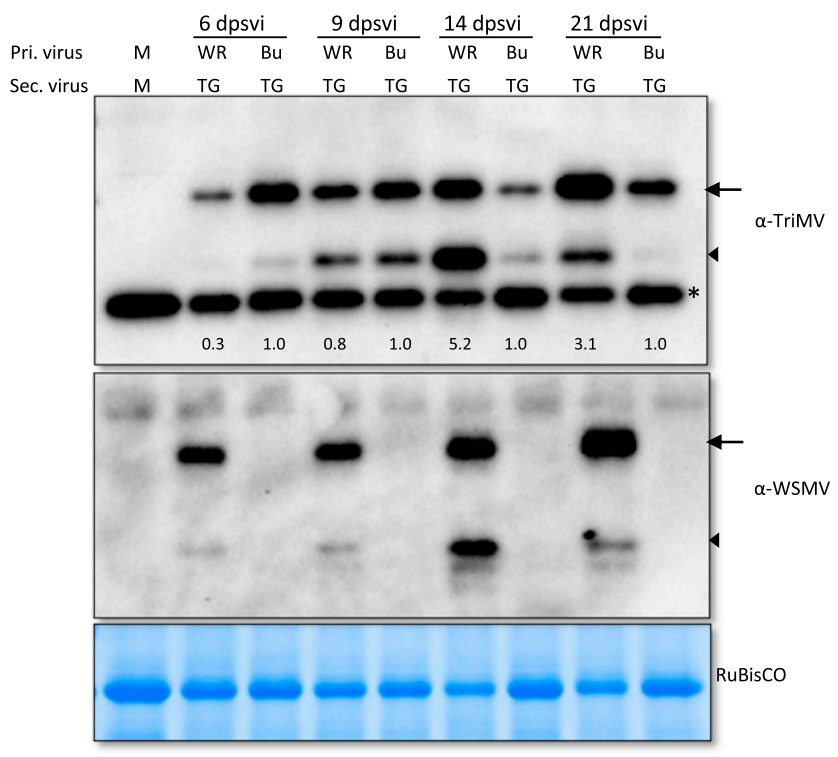

Fig. 7. Wheat infected by Wheat streak mosaic virus (WSMV)-red fluorescent protein (RFP) affected accumulation of Triticum mosaic virus (TriMV)-green fluorescent protein (GFP) in upper uninoculated leaves. Western blot analysis of total proteins from wheat infected by WSMV-RFP (primary virus) followed by TriMV-GFP at $6,8,14$, and 21 days postsecondary virus inoculation (dpsvi). Numbers at the bottom of the immunoblot with TriMV antibodies show accumulation of TriMV coat protein (CP)-specific major protein (secondary virus) in wheat preinfected with WSMV-RFP compared with that of buffer-inoculated wheat at $6,8,14$, and 21 dpsvi. The bottom panel of the immunoblot is probed with WSMV-specific polyclonal antibodies. The fulllength $\mathrm{CP}$ and a truncated minor $\mathrm{CP}$ that reacted positively with WSMV or TriMV antibodies are indicated with arrows and arrowheads, respectively. A wheat protein that nonspecifically reacted with TriMV polyclonal antibodies is indicated with an asterisk. A Coomassie-stained sodium dodecyl sulfate polyacrylamide gel electrophoresis gel, shown below the immunoblots, is wheat RuBisCO protein indicating the amount of protein loaded per well. Western blot analysis of total proteins with WSMV and TriMV polyclonal antibodies was performed from three independent experiments, and representative blots from one experiment are presented. WR $=$ WSMV-RFP, TG = TriMV-GFP, and $\mathrm{Bu}=$ buffer.

Table 4. (Continued from previous page)

\begin{tabular}{|c|c|c|c|c|c|}
\hline \multicolumn{6}{|c|}{ Number of genomic RNA copies per $10 \mathrm{ng}$ of total $\mathrm{RNA}^{\mathrm{b}}$} \\
\hline \multicolumn{3}{|c|}{ Time point 3} & \multicolumn{3}{|c|}{ Time point 4} \\
\hline 24 dpi & 14 dpsvi & & 31 dpi & 21 dpsvi & \\
\hline WSMV-RFP & TriMV-GFP & FC & WSMV-RFP & TriMV-GFP & FC \\
\hline $\begin{array}{l}0 \\
8.6 \times 10^{5} \pm 3.4 \times 10^{4}\end{array}$ & $\begin{array}{l}1.6 \times 10^{5} \pm 3.3 \times 10^{3} \\
2.2 \times 10^{6} \pm 1.0 \times 10^{5}\end{array}$ & $\ldots$ & $\begin{array}{l}0 \\
2.4 \times 10^{5} \pm 3.1 \times 10^{4}\end{array}$ & $\begin{array}{l}1.8 \times 10^{5} \pm 7.5 \times 10^{3} \\
7.3 \times 10^{5} \pm 1.2 \times 10^{5}\end{array}$ & 4.1*** \\
\hline $\begin{array}{l}0 \\
7.1 \times 10^{5} \pm 5.1 \times 10^{4}\end{array}$ & $\begin{array}{l}1.1 \times 10^{4} \pm 2.6 \times 10^{2} \\
3.3 \times 10^{5} \pm 3.7 \times 10^{4}\end{array}$ & $29.5^{* * *}$ & $\begin{array}{l}0 \\
2.9 \times 10^{4} \pm 1.5 \times 10^{3}\end{array}$ & $\begin{array}{l}1.7 \times 10^{4} \pm 2.5 \times 10^{3} \\
2.3 \times 10^{4} \pm 1.7 \times 10^{3}\end{array}$ & $1.3^{\text {ns }}$ \\
\hline
\end{tabular}


GFP or RFP fluorescence images of local foci and systemic infection by WSMV-RFP or TriMV-GFP were obtained with an AxioCam MRc5 camera attached to the fluorescent microscope. Synergistic interaction experiments between fluorescent protein-tagged WSMV and TriMV were repeated three times and a representative of one experiment was presented in Figures 1 and 2.

\section{Examining synergistic interaction between WSMV and TriMV by sequential inoculation.}

Wheat seedlings were inoculated at the single-leaf stage with crude sap of wheat leaves infected by WSMV-RFP or TriMVGFP at 1:20 dilution and incubated in a greenhouse. Buffer-

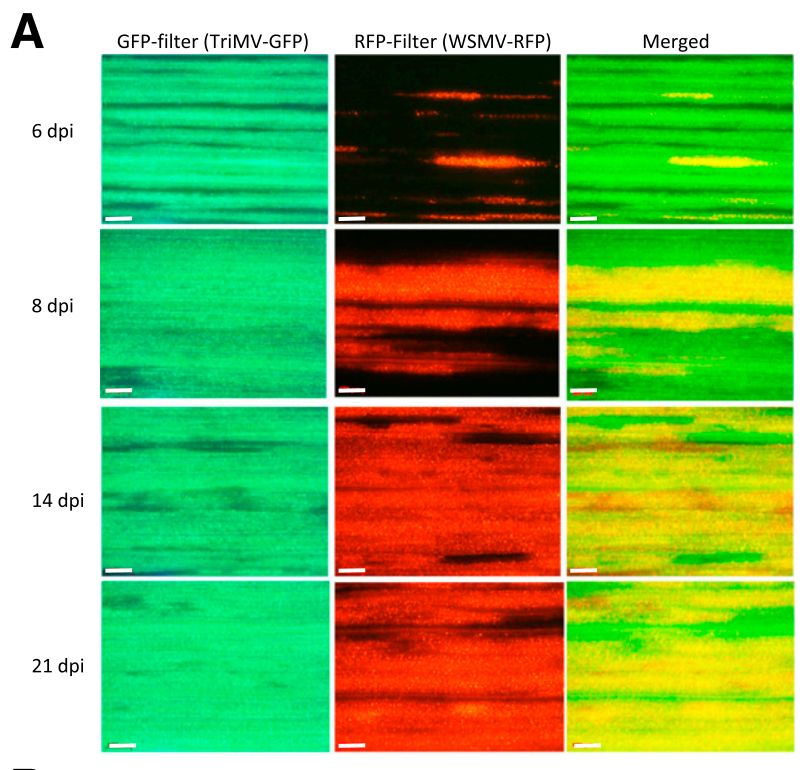

B

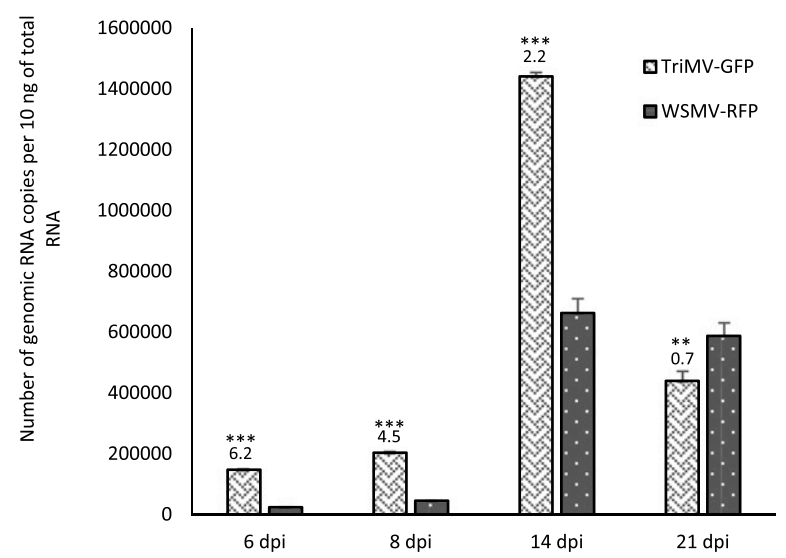

Fig. 8. Triticum mosaic virus (TriMV) facilitated enhanced long-distance movement compared with Wheat streak mosaic virus (WSMV) in coinoculated wheat during early stages of synergistic interaction. A, Fluorescent images of upper uninoculated wheat leaves under a green fluorescent protein (GFP) filter (for TriMV-GFP infection) and red fluorescent protein (RFP) filter (for WSMV-RFP infection) from wheat coinoculated with WSMV-RFP+TriMV-GFP. Note that GFP fluorescence covered most of the leaf lamina compared with isolated foci of WSMV-RFP at 6 and 8 days postinoculation (dpi). Merged pictures show coinfection by TriMV-GFP and WSMV-RFP. Bars represent $500 \mu \mathrm{m}$. B, Quantification of genomic RNA copies of WSMV and TriMV from upper uninoculated leaves of wheat coinoculated with WSMV-RFP+TriMV-GFP at 6, 8, 14, and 21 dpi. Vertical bars represent standard error. Numbers presented above the histograms of TriMV genomic RNA copies are the fold change in genomic RNA accumulation over WSMV genomic RNA copies at respective time-point. Asterisks $* *$ and $* * *$ represent statistical significance at a confidence interval of 95 and $99 \%$, respectively. inoculated wheat seedlings were used as a negative control. The fully expanded symptomatic third leaves of wheat infected by WSMV-RFP or TriMV-GFP at 10 dpi were inoculated with 1: 30 diluted crude sap prepared from freshly infected wheat by TriMV-GFP or WSMV-RFP, respectively, by swiping two to three times from the bottom of the leaf to the top between an inoculum-dipped index finger and thumb. Similarly, the third leaves of buffer-inoculated wheat were inoculated with crude sap of WSMV-RFP, TriMV-GFP, or both at 1:30 dilution. Wheat plants superinoculated with the SIP virus were incubated in a growth chamber at $23^{\circ} \mathrm{C}$ (maximum) and $20^{\circ} \mathrm{C}$ (minimum) with $14 \mathrm{~h}$ of light $\left(210 \mu \mathrm{mol} \mathrm{m}^{-2} \mathrm{~s}^{-1}\right)$. The development of local foci at 3 and 5 dpsvi and systemic infection at $6,8,14$, and 21 dpsvi by the secondary virus was examined under a fluorescent dissecting microscope, as described above. The average size of foci elicited by the secondary virus was measured for 20 to 25 isolated foci at the center of inoculated leaves with 1 or 2 foci per leaf from 10 to 15 inoculated leaves by using a program provided with the AxioCam MRc5 camera, as described by Tatineni et al. (2016). The number and size of local foci developed by a secondary SIP virus on primary SIP virus-infected wheat were analyzed compared with bufferinoculated plants for differences in mean values by unpaired Welch's $t$ test to account for unequal variances in $\mathrm{R}$ (Welch 1951). Systemic infection by the secondary virus was examined under a fluorescent dissecting microscope from upper uninoculated leaves from 15 to 20 plants. The genomic RNA copies and accumulation of $\mathrm{CP}$ of primary and secondary viruses were estimated from the same pool of leaf tissue.

\section{Quantification of genomic RNA copies of WSMV and TriMV.}

Total RNA was extracted from each sample in triplicate from $200 \mathrm{mg}$ of tissue using TriPure reagent (Roche, Indianapolis, IN), as described by Tatineni et al. (2010). Random primed cDNA from $1 \mu \mathrm{g}$ of total RNA was diluted to $1: 10$ and $1 \mu \mathrm{l}$ of

Table 5. Triticum mosaic virus (TriMV) facilitated enhanced long-distance movement compared with Wheat streak mosaic virus (WSMV) in coinoculated wheat during early stages of synergistic interaction ${ }^{\mathrm{a}}$

\begin{tabular}{|c|c|c|c|c|c|c|c|}
\hline \multirow[b]{3}{*}{$\begin{array}{l}\text { Exp, } \\
\text { dpi }\end{array}$} & \multirow[b]{3}{*}{$\begin{array}{c}\text { Inoc } \\
(n)\end{array}$} & \multirow{2}{*}{\multicolumn{3}{|c|}{$\begin{array}{c}\text { Systemic infection of } \\
\text { WSMV-RFP in } \\
\text { coinoculated wheat } \\
\text { Plants with RFP } \\
\text { expression }(\%)\end{array}$}} & \multirow{2}{*}{\multicolumn{3}{|c|}{$\begin{array}{c}\text { Systemic infection of } \\
\text { TriMV-GFP in } \\
\text { coinoculated wheat } \\
\text { Plants with GFP } \\
\text { expression }(\%)\end{array}$}} \\
\hline & & & & & & & \\
\hline & & Strong & Weak & $\begin{array}{c}\text { No } \\
\text { RFP }\end{array}$ & Strong & Weak & $\begin{array}{c}\text { No } \\
\text { RFP }\end{array}$ \\
\hline \multicolumn{8}{|l|}{ I } \\
\hline $6 * * *$ & 15 & 33 & 67 & 0 & 87 & 13 & 0 \\
\hline $8 * * *$ & 11 & 50 & 50 & 0 & 100 & 0 & 0 \\
\hline $14^{\mathrm{ns}}$ & 14 & 100 & 0 & 0 & 100 & 0 & 0 \\
\hline \multicolumn{8}{|l|}{ II } \\
\hline $6 * * *$ & 13 & 0 & 58 & 42 & 77 & 16 & 8 \\
\hline $8 * * *$ & 13 & 46 & 54 & 0 & 100 & 0 & 0 \\
\hline $14^{\mathrm{ns}}$ & 14 & 100 & 0 & 0 & 100 & 0 & 0 \\
\hline \multicolumn{8}{|l|}{ III } \\
\hline $6 * * *$ & 11 & 36 & 64 & 0 & 91 & 9 & 0 \\
\hline $8 * * *$ & 19 & 63 & 37 & 0 & 100 & 0 & 0 \\
\hline $14^{\mathrm{ns}}$ & 15 & 100 & 0 & 0 & 100 & 0 & 0 \\
\hline
\end{tabular}

${ }^{a}$ Fully expanded third leaves of wheat seedlings were coinoculated with WSMV-red fluorescent protein (RFP) + TriMV-green fluorescent protein (GFP) with 1:30 dilution of crude sap extracted from in vitro transcriptinfected wheat leaves. Inoc $(n)=$ number of plants inoculated.

${ }^{\mathrm{b}}$ In three experiments (Exp), infections by WSMV-RFP and TriMV-GFP in coinoculated wheat plants were compared by $\chi^{2}$ analysis. Asterisks (***) indicate statistically significant at $P<0.01$, ns $=$ not statistically significant, and dpi = days postinoculation. 
diluted cDNAs were used for real-time PCR using TaqMan DNA polymerase (Applied Biosystems, Foster City, CA) using WSMV or TriMV CP-specific primers and probe, as described by Tatineni et al. (2010). The number of genomic RNA copies of WSMV and TriMV were calculated from the threshold cycle $(\mathrm{Ct})$ values of each sample in triplicate by normalized expression of each sample based on the $\mathrm{Ct}$ value of wheat 18S RNA using Q-Gene software (Pfaffl et al. 2002). Differences in mean values were analyzed by unpaired Welch's $t$ test to account for unequal variances in $\mathrm{R}$ (Welch 1951).

\section{Western blot assays.}

Total protein was extracted from the same batch of wheat tissue that was used for total RNA isolation. Wheat tissue (300 mg) collected from upper uninoculated leaves into mesh bags (Agdia, Elkhart, IN) was stored at $-80^{\circ} \mathrm{C}$ for total protein extraction, as described by Tatineni et al. (2016). Total proteins separated through 4 to $20 \%$ Tris-glycine sodium dodecyl sulfate polyacrylamide gels (Invitrogen, Carlsbad, CA) were transferred onto polyvinylidene difluoride (PVDF) membranes for immunodetection using polyclonal antibodies raised against TriMV $\mathrm{CP}$ or WSMV virions, as described by Tatineni and French (2016). Immunoreactive protein images specific to WSMV or TriMV CP on PVDF membranes were obtained using the Molecular Imager ChemiDoc XRS+ with Image Lab software system (Bio-Rad, Hercules, CA). The major protein band specific to WSMV or TriMV CP were quantified with the Molecular Imager ChemiDoc XRS+ system.

\section{LITERATURE CITED}

Brakke, M. K. 1987. Virus disease in wheat. Pages 585-603 in: Wheat and Wheat Improvement, 2nd ed. E. G. Heyne, ed. American Society of Agronomy, Crop Science Society of America, Soil Science Society of America, Madison, WI.

Burrows, M., Franc, G., Rush, C., Blunt, T., Ito, D., Kinzer, K., Olson, J., O'Mara, J., Price, J., Tande, C., Ziems, A., and Stack, J. 2009. Occurrence of viruses in wheat in the Great Plains region, 2008. Online publication. Plant Health Prog. 10.

Byamukama, E., Seifers, D. L., Hein, G. L., De Wolf, E., Tisserat, N. A., Langham, M. A. C., Osborne, L. E., Timmerman, A., and Wegulo, S. N. 2013. Occurrence and distribution of Triticum mosaic virus in the central Great Plains. Plant Dis. 97:21-29.

Byamukama, E., Tatineni, S., Hein, G. L., Graybosch, R. A., Baenziger, P. S., French, R., and Wegulo, S. N. 2012. Effects of single and double infections of winter wheat by Triticum mosaic virus and Wheat streak mosaic virus on yield determinants. Plant Dis. 96:859-864.

Byamukama, E., Tatineni, S., Hein, G. L., Graybosch, R. A., Baenziger, P. S., French, R. C., and Wegulo, S. N. 2014. Quantification of yield loss caused by Triticum mosaic virus and Wheat streak mosaic virus in winter wheat under field conditions. Plant Dis. 98:127-133.

Chávez-Calvillo, G., Contreras-Paredes, C. A., Mora-Macias, J., NoaCarrazana, J. C., Serrano-Rubio, A. A., Dinkova, T. D., Carrillo-Tripp, M., and Silva-Rosales, L. 2016. Antagonism or synergism between papaya ringspot virus and papaya mosaic virus in Carica papaya is determined by their order of infection. Virology 489:179-191.

Choi, I. R., French, R., Hein, G. L., and Stenger, D. C. 1999. Fully biologically active in vitro transcripts of the eriophyid mite-transmitted wheat streak mosaic tritimovirus. Phytopathology 89:1182-1185.

Choi, I. R., Horken, K. M., Stenger, D. C., and French, R. 2005. An internal RNA element in the P3 cistron of Wheat streak mosaic virus revealed by synonymous mutations that affect both movement and replication. J. Gen. Virol. 86:2605-2614.

Fellers, J. P., Seifers, D., Ryba-White, M., and Martin, T. J. 2009. The complete genome sequence of Triticum mosaic virus, a new wheatinfecting virus of the High Plains. Arch. Virol. 154:1511-1515.

French, R., and Stenger, D. C. 2004. Wheat streak mosaic virus. Pages 602-604 in: Viruses and Virus Diseases of Poaceae. H. Lapierre and P. Signoret, eds. INRA Editions, Paris.

Fukuzawa, N., Itchoda, N., Ishihara, T., Goto, K., Masuta, C., and Matsumura, T. 2010. HC-Pro, a potyvirus RNA silencing suppressor, cancels cycling of Cucumber mosaic virus in Nicotiana benthamiana plants. Virus Genes 40:440-446.
González-Jara, P., Atencio, F. A., Martínez-García, B., Barajas, D., Tenllado, F., and Díaz-Ruíz, J. R. 2005. A single amino acid mutation in the Plum pox virus helper component-proteinase gene abolishes both synergistic and RNA silencing suppression activities. Phytopathology 95:894-901.

González-Jara, P., Tenllado, F., Martínez-García, B., Atencio, F. A., Barajas, D., Vargas, M., Díaz-Ruiz, J., and Díaz-Ruíz, J. R. 2004. Hostdependent differences during synergistic infection by Potyviruses with potato virus X. Mol. Plant Pathol. 5:29-35.

Gutiérrez, D. L., Fuentes, S., and Salazar, L. F. 2003. Sweet potato virus disease (SPVD): Distribution, incidence, and effect on sweet potato yield in Peru. Plant Dis. 87:297-302.

Hisa, Y., Suzuki, H., Atsumi, G., Choi, S. H., Nakahara, K. S., and Uyeda, I. 2014. P3N-PIPO of Clover yellow vein virus exacerbates symptoms in pea infected with white clover mosaic virus and is implicated in viral synergism. Virology 449:200-206.

Karyeija, R. F., Kreuze, J. F., Gibson, R. W., and Valkonen, J. P. T. 2000. Synergistic interactions of a potyvirus and a phloem-limited crinivirus in sweet potato plants. Virology 269:26-36.

Kasschau, K. D., Xie, Z., Allen, E., Llave, C., Chapman, E. J., Krizan, K. A., and Carrington, J. C. 2003. P1/HC-Pro, a viral suppressor of RNA silencing, interferes with Arabidopsis development and miRNA unction. Dev. Cell 4:205-217.

Mahuku, G., Lockhart, B. E., Wanjala, B., Jones, M. W., Kimunye, J. N., Stewart, L. R., Cassone, B. J., Sevgan, S., Nyasani, J. O., Kusia, E., Kumar, P. L., Niblett, C. L., Kiggundu, A., Asea, G., Pappu, H. R., Wangai, A., Prasanna, B. M., and Redinbaugh, M. G. 2015. Maize lethal necrosis (MLN), an emerging threat to maize-based food security in subSharan Africa. Phytopathology 105:956-965.

Malapi-Nelson, M., Wen, R. H., Ownley, B. H., and Hajimorad, M. R. 2009. Co-infection of soybean with Soybean mosaic virus and Alfalfa mosaic virus results in disease synergism and alteration in accumulation level of both viruses. Plant Dis. 93:1259-1264.

Mascia, T., Cillo, F., Fanelli, V., Finetti-Sialer, M. M., De Stradis, A., Palukaitis, P., and Gallitelli, D. 2010. Characterization of the interactions between Cucumber mosaic virus and Potato virus $Y$ in mixed infections in tomato. Mol. Plant-Microbe Interact. 23:1514-1524.

Mascia, T., and Gallitelli, D. 2016. Synergies and antagonisms in virus interactions. Plant Sci. 252:176-192.

McMechan, A. J., Tatineni, S., French, R., and Hein, G. L. 2014. Differential transmission of Triticum mosaic virus by wheat curl mite populations collected in the Great Plains. Plant Dis. 98:806-810.

Nelson, R. S., and Citovsky, V. 2005. Plant viruses. Invaders of cells and pirates of cellular pathways. Plant Physiol. 138:1809-1814.

Patil, B. L., Legg, J. P., Kanju, E., and Fauquet, C. M. 2015. Cassava brown streak disease: A threat to food security in Africa. J. Gen. Virol. 96: 956-968.

Pfaffl, M. W., Horgan, G. W., and Dempfle, L. 2002. Relative expression software tool (REST) for group-wise comparison and statistical analysis of relative expression results in real-time PCR. Nucleic Acids Res. 30:e36.

Pruss, G., Ge, X., Shi, X. M., Carrington, J. C., and Vance, V. B. 1997. Plant viral synergism: The potyviral genome encodes a broad-range pathogenicity enhancer that transactivates replication of heterologous viruses. Plant Cell 9:859-868.

Rabindran, S., and Dawson, W. O. 2001. Assessment of recombinants that arise from the use of a TMV-based transient expression vector. Virology 284:182-189.

Redinbaugh, M.G., and Stewart, L. R. 2018. Maize lethal necrosis: An emerging, synergistic viral disease. Annu. Rev. Virol. 5:301-322.

Scheets, K. 1998. Maize chlorotic mottle machlomovirus and Wheat streak mosaic rymovirus concentrations increase in the synergistic disease corn lethal necrosis. Virology 242:28-38.

Seifers, D. L., Martin, T. J., Harvey, T. L., Fellers, J. P., and Michaud, J. P. 2009. Identification of the wheat curl mite as the vector of Triticum mosaic virus. Plant Dis. 93:25-29.

Seifers, D. L., Martin, T. J., Harvey, T. L., Fellers, J. P., Stack, J. P., RybaWhite, M., Haber, S., Krokhin, O., Spicer, V., Lovat, N., Yamchuk, A., and Standing, K. G. 2008. Triticum mosaic virus: A new virus isolated from wheat in Kansas. Plant Dis. 92:808-817.

Shi, X. M., Miller, H., Verchot, J., Carrington, J. C., and Vance, V. B. 1997. Mutations in the region encoding the central domain of helper component-proteinase (HC-Pro) eliminate potato virus X/potyviral synergism. Virology 231:35-42.

Slykhuis, J. T. 1955. Aceria tulipae Keifer (Acarina: Eriophyidae) in relation to spread of wheat streak mosaic virus. Phytopathology 45:116-128.

Stenger, D. C., French, R., and Gildow, F. E. 2005a. Complete deletion of Wheat streak mosaic virus HC-Pro: A null mutant is viable for systemic infection. J. Virol. 79:12077-12080. 
Stenger, D. C., Hall, J. S., Choi, I.-R., and French, R. 1998. Phylogenetic relationships within the family potyviridae: Wheat streak mosaic virus and Brome streak mosaic virus are not members of the genus rymovirus. Phytopathology 88:782-787.

Stenger, D. C., Hein, G. L., and French, R. 2006. Nested deletion analysis of Wheat streak mosaic virus HC-Pro: Mapping of domains affecting polyprotein processing and eriophyid mite transmission. Virology 350:465-474.

Stenger, D. C., Hein, G. L., Gildow, F. E., Horken, K. M., and French, R. 2005b. Plant virus HC-Pro is a determinant of eriophyid mite transmission. J. Virol. 79:9054-9061.

Stenger, D. C., Young, B. A., Qu, F., Morris, T. J., and French, R. 2007. Wheat streak mosaic virus lacking helper component-proteinase is competent to produce disease synergism in double infections with Maize chlorotic mottle virus. Phytopathology 97:1213-1221.

Syller, J. 2012. Facilitative and antagonistic interactions between plant viruses in mixed infections. Mol. Plant Pathol. 13:204-216.

Syller, J., and Grupa, A. 2016. Antagonistic within-host interactions between plant viruses: Molecular basis and impact on viral and host fitness. Mol. Plant Pathol. 17:769-782.

Tatineni, S. 2017. Wheat streak mosaic virus coat protein is a host-specific long-distance transport determinant in oat. Virus Res. 242:37-42.

Tatineni, S., Elowsky, C., and Graybosch, R. A. 2017. Wheat streak mosaic virus coat protein deletion mutants elicit more severe symptoms than wildtype virus in multiple cereal hosts. Mol. Plant-Microbe Interact. 30:974-983.

Tatineni, S., and French, R. 2016. The coat protein and NIa protease of two potyviridae family members independently confer superinfection exclusion. J. Virol. 90:10886-10905.

Tatineni, S., Graybosch, R. A., Hein, G. L., Wegulo, S. N., and French, R. 2010. Wheat cultivar-specific disease synergism and alteration of virus accumulation during co-infection with Wheat streak mosaic virus and Triticum mosaic virus. Phytopathology 100:230-238.

Tatineni, S., Kovacs, F., and French, R. 2013. Wheat streak mosaic virus infects systemically despite extensive coat protein deletions: Identification of virion assembly and cell-to-cell movement determinants. J. Virol. 88:1366-1380.

Tatineni, S., McMechan, A. J., Bartels, M., Hein, G. L., and Graybosch, R. A. 2015. In vitro transcripts of wild-type and fluorescent proteintagged Triticum mosaic virus (family Potyviridae) are biologically active in wheat. Phytopathology 105:1496-1505.
Tatineni, S., McMechan, A. J., and Hein, G. L. 2018. Wheat streak mosaic virus coat protein is a determinant for vector transmission by the wheat curl mite. Virology 514:42-49.

Tatineni, S., McMechan, A. J., Hein, G. L., and French, R. 2011a. Efficient and stable expression of GFP through Wheat streak mosaic virus-based vectors in cereal hosts using a range of cleavage sites: Formation of dense fluorescent aggregates for sensitive virus tracking. Virology 410:268-281.

Tatineni, S., Qu, F., Li, R., Morris, T. J., and French, R. 2012. Triticum mosaic poacevirus enlists $\mathrm{P} 1$ rather than HC-Pro to suppress RNA silencing-mediated host defense. Virology 433:104-115.

Tatineni, S., Van Winkle, D. H., and French, R. 2011b. The N-terminal region of wheat streak mosaic virus coat protein is a host- and strainspecific long-distance transport factor. J. Virol. 85:1718-1731.

Tatineni, S., Wosula, E. N., Bartels, M., Hein, G. L., and Graybosch, R. A. 2016. Temperature-dependent Wsm1 and Wsm2 gene-specific blockage of viral long-distance transport provides resistance to Wheat streak mosaic virus and Triticum mosaic virus in wheat. Mol. Plant-Microbe Interact. 29:724-738.

Tatineni, S., Ziems, A. D., Wegulo, S. N., and French, R. 2009. Triticum mosaic virus: A distinct member of the family potyviridae with an unusually long leader sequence. Phytopathology 99:943-950.

Valkonen, J. P. T. 1992. Accumulation of potato virus $\mathrm{Y}$ is enhanced in Solatium brevidens also infected with tobacco mosaic virus or potato spindle tuber viroid. Ann. Appl. Biol. 121:321-327.

Vance, V. B. 1991. Replication of potato virus X RNA is altered in coinfections with potato virus Y. Virology 182:486-494.

Vance, V. B., Berger, P. H., Carrington, J. C., Hunt, A. G., and Shi, X. M. 1995. 5' proximal potyviral sequences mediate potato virus X/potyviral synergistic disease in transgenic tobacco. Virology 206:583-590.

Welch, B. L. 1951. On the comparison of several mean values: An alternative approach. Biometrika 38:330-336.

Whitfield, A. E., Falk, B. W., and Rotenberg, D. 2015. Insect vectormediated transmission of plant viruses. Virology 479-480:278-289.

Young, B. A., Stenger, D. C., Qu, F., Morris, T. J., Tatineni, S., and French, R. 2012. Tritimovirus P1 functions as a suppressor of RNA silencing and an enhancer of disease symptoms. Virus Res. 163:672-677.

Zhang, X.-F., Zhang, S., Guo, Q., Sun, R., Wei, T., and Qu, F. 2018. A New Mechanistic Model for Viral Cross Protection and Superinfection Exclusion. Front. Plant Sci. 9:40. 